\title{
Tekniken, jämställdheten och fritiden
}

\author{
En ny behovsbild
}

Ovan har jag framförallt belyst åtgärder för attityd- och intressepåverkan såsom de tog sig uttryck i kursplaner, läromedel, laborationer, studievägledning och betygsättning - verksamheter som alla försiggick inom skolans traditionellt avgränsade praktik och ansvarsdomäner. I detta kapitel har jag berett mer plats för andra sammanhang; aktiviteter som på många sätt kan betecknas som utbildande inom naturvetenskap och teknik men som ofta ägde rum i andra miljöer än klassrummet och fysiksalen, ibland helt utanför skolans område. Vi har redan snuddat vid arrangemang som Berzeliusdagarna under 1950-talet, Utställningen Unga Forskare ett decennium senare och de båda vetenskapsolympiaderna under 1970-talet. Exemplen visar att andra aktörer än statliga myndigheter tidigt sökte nya strategier för att vägleda unga människor till livslånga intressen för naturvetenskap och teknik.

Under 1980-talet skulle sådana initiativ mångfaldigas. Lika ofta som de kom från Skolöverstyrelsen och Utbildningsdepartementet hade de sitt ursprung hos intresseorganisationer, museer, tidningar och företrädare för industrin. Tillvägagångssättet följde dock samma mönster som innanför skolväggarna. Medvetet utformade situationer för lärande och information skulle locka elever att fatta tycke för ett yrke som ingenjör eller naturvetare, samtidigt som beslutet skulle vara ett uttryck för deras eget handlande. I takt med att fler aktörer bejakade problembeskrivningen blev rekryteringspolitiken alltmer omfattande både med avseende på geografisk utbredning och intellektuell variation. Detta bidrog också till att föra den in i nya institutionella former.

Vi börjar dock där föregående kapitel slutade. Efter några år av osäkerhet om arbetsmarknadens behov till följd av "naturvetarkrisen" kom signaler om en förestående högkonjunktur. Statistiken från näringslivet 
skapade efter hand en opinion för kraftigt ökad rekrytering i mitten av 1980-talet. Budskapet presenterades i ett flertal skrifter, däribland boken Var finns teknikerna för svensk industri? som Industriförbundet, Svenska Arbetsgivareföreningen och Sveriges Verkstadsförening gav ut tillsammans för att nå större resultat. Där pekade de på en förestående teknikerbrist främst inom områden som data, elektronik och telekommunikation. Som motåtgärd krävde de en väsentligt ökad tillgång på ingenjörer och nya resurser till tekniska utbildningar. ${ }^{384}$

Den socialdemokratiska utbildningsministern Lena Hjelm-Wallén kommenterade den nya problematiska situationen i dagspressen. Där återupprepades de motstridiga trender och budskap som så ofta omgav rekryteringsfrågan. Å ena sidan framkom att utvecklingen på gymnasiet var god. Nedgången för ansökningar till den naturvetenskapliga linjen hade bromsats och eleverna på den tekniska linjen ökade kraftigt. Sammantaget var de båda utbildningarna tillsammans större än någonsin tidigare. Å andra sidan påpekade ministern att trots de goda siffrorna hade flera åtgärder redan satts in för att öka tillströmningen. Fler initiativ skulle följa för att möta de både långsiktiga och kortsiktiga behoven. ${ }^{385}$

Budskapet om en fortsatt expansiv enrolleringspolitik var en indikation på att regeringen Palme efter maktskiftet 1982 hade förstärkt åtgärderna som skulle locka unga människor till de prioriterade utbildningarna. Under 1980-talet skulle tidigare ekonomiska ramar för ändamålet komma att sprängas. De ökade resurserna indikerade att problembilden uppfattades som större än tidigare. Den otillräckliga tillströmningen hade vid det här laget blivit ett samhälleligt orosmoment med flera lager. Medan nationalekonomiska bevekelsegrunder nästan alltid gjorde sig påminda, ackompanjerades de allt oftare av ytterligare skäl som gav anledning till handlande. Miljödebattens varningar om teknikens konsekvenser hade transformerats till motiv för att närma sig vetenskapen snarare än att undvika den. Därtill fanns uppfattningen att fler yrkesgrupper borde skaffa sig en djupare teknisk och vetenskaplig medborgarbildning. Mot bakgrund av detta anfördes att fler journalister, bibliotekarier eller tjänstemän på olika nivåer borde ha någon form av naturvetenskaplig examen.

Lena Hjelm-Walléns argumentation för förstärkta åtgärder var dock framförallt jämställdhetspolitiskt motiverad. Flickors representation på tekniska utbildningar var fortfarande mycket svag. Här fanns visserligen ljuspunkter i form av en stigande trend, men siffrorna växte från mycket 
låga utgångstal. På den fyraåriga tekniska utbildningen vid gymnasierna hade flickors andel ökat från 7 procent till 12 procent under 1970-talet och siffrorna för de första åren under det kommande decenniet indikerade en fortsatt försiktig ökning. På de tvååriga yrkestekniska utbildningarna som till exempel bygg- och anläggning, verkstadsteknik, fordonsteknik och el-teleteknik kom andelen flickor knappt över 4 procent under hela 1980-talet. På högre nivåer i systemet var situationen likartad. Siffror för de tekniska högskolornas grundutbildningar vid samma tid bekräftar bilden av en långsamt ökande andel kvinnor. ${ }^{386}$

\section{Ingenjörsyrket som jämställdhetsprojekt}

Hjelm-Wallén betraktade den verklighet om vilken statistiken talade som bekymmersam, inte endast för industrins vidkommande utan också för kvinnorna själva. Framtidens arbetsmarknad uppfattades till stor del ligga i de tekniska yrkesgrenarna:

Mycket talar för att många av de arbetsuppgifter som kvinnor i dag har inom tillverkningsindustrin och inom handel och kontor är allvarligt hotade i nästa rationaliseringsvåg. Samtidigt byggs offentliga sektorn inte längre ut i samma utsträckning som tidigare. Det är helt nödvändigt för kvinnorna att slå sig in på den mansdominerade sektorn av industrin om de vill behålla sin ställning på arbetsmarknaden. ${ }^{387}$

I den växande debatten om kvinnor, teknik och samhälle hördes flera olika argument som knöt an till arbetsmarknaden. De tog inte endast fasta på att undvika arbetslöshet utan också på kvinnors rätt till arbeten med god löneutveckling och högre grad av meningsfullhet. I kampanjer riktade till flickor framställdes olika tekniska yrken som synonyma med kvalificerade arbetsuppgifter, bättre lön och status i arbetslivet. De porträtterades också som goda plattformar för att kunna delta i den tekniska samhällsdebatten. ${ }^{388}$

Det betydde också att argumenten för flickors val av teknik hade fortsatt att breddas. Kvinnan-som-ingenjör kunde nu framställas som en allt viktigare identitet även för den enskilda individen som ansågs ha rätt till goda livsvillkor. Sammantaget gjorde det att jämställdhetsgrundade motiv för fler kvinnliga ingenjörer bitvis blev mer jämnstarka med sådana som tog fasta på den ekonomiska situationen. Argumenten formulerades heller 
inte i motsats till varandra. Snarare kom sammanförandet av den emancipatoriska politiken och de mer nyttopräglade idéerna att komplettera och öka den sammanlagda behovsbilden.

Att rekryteringspolitiken successivt inkorporerade jämställdhetsfrågan formade således en större reservoar av argument för att driva kampanjer och att lösgöra resurser. Identifierandet av flickor som föremål för liberalt styre kunde därmed göras av fler skäl. Som ett resultat av detta skulle stora delar av de rekryteringspolitiska satsningarna från regeringen under 1980-talet komma att koncentreras till relationerna mellan kvinnor och teknik. ${ }^{389}$

Ett exempel på detta är införandet av grundskolans obligatoriska teknikämne i början av decenniet. När Lena Hjelm-Wallén uttalade sig i dagspressen om behovet av långsiktiga åtgärder framhöll hon speciellt denna satsning som betydelsefull. Det var viktigt, menade ministern, att vänja flickor vid tekniska samband i tidiga åldrar. ${ }^{390}$ Teknikämnets införande i läroplanen Lgr 80 hade utarbetats under den föregående borgerliga regeringens mandatperiod och hade sin grund i en mångfacetterad behovsbild. I dess tillkomst investerades förhoppningar om att stärka en teknisk medborgarbildning och öka inslag av praktiska arbetssätt i skolan, men därtill kom mer direkta motiv om att stimulera fler elever, helst flickor, att utveckla identiteter och välja yrken med teknisk och naturvetenskaplig profil. ${ }^{391}$

De många förväntningar som knöts till det nya skolämnet gjorde att dess profil och tillhörighet inledningsvis framstod som oklar, något som blev en påminnelse om dess historiskt sett tämligen vaga identitet. Procedurerna runt ämnets klassificering var svåra för Skolöverstyrelsen att bemästra, bland annat för att det enda undervisningsinnehåll som liknade en föregångare var de två industriorienterade tillvalsämnena "teknisk orientering" i Lgr 62 och "teknik" i Lgr 69. Konkurrerande gränsdragningar blev tydliga och blottlade att det ingalunda var okomplicerat att sammanföra naturvetenskap och teknik till en kategori. Till en början sökte Skolöverstyrelsen främst gruppera ämnet tillsammans med slöjd, någonting som kunde framstå som naturligt i ljuset av en äldre folkskoletradition. Teknik och slöjd hade under flera decennier förmedlat närbesläktade kunskaper om i huvudsak praktiska arbetsformer för lägre åldrar. Ett kombinerat slöjd-och-teknik-ämne betraktades därför som ett lämpligt sätt att öka inslaget av konkreta, vardagliga arbetssätt i undervisningen. ${ }^{392}$ 
Tanken på slöjd-teknik utmanade sammanförandet av naturvetenskapen och tekniken som det mest självklara i didaktiska sammanhang. Efter att Utbildningsdepartementet ingripit alltmer i processen fördes dock ämnet till den naturorienterade ämnesgruppen. Rekryteringsbehovet spelade en betydande roll i det beslutet eftersom det hade sina förespråkare både på departementet, i övriga riksdagspartier och bland många remissinstanser. Inte minst hade sådana argument visat sig i samband med partiernas oro för "naturvetarkrisen" i slutet av 1970-talet. ${ }^{393}$ Det slutgiltiga läroplansförslaget hänvisade till de "naturliga beröringspunkter" som fanns mellan de båda ämnena. ${ }^{394}$ Det var en uppfattning som senare förtydligades i en proposition 1978:

Internationella studier har framhävt betydelsen av att naturvetenskap och teknik behandlas som en enhet vid undervisningen. Denna enhet måste framstå tydlig för eleverna både i början och vid slutet av ett avsnitt. Teori och tillämpning måste också vara intimt förbundna. En undervisning där detta samband inte ständigt framgår förfelar sitt syfte. ${ }^{395}$

Teknikämnet skulle även fortsättningsvis under 1980-talet komma att vara förknippat med en mängd olika förhoppningar. När Skolöverstyrelsens generaldirektör Lennart Orehag i tidskriften Pedagogiskt magazin kommenterade det nya inslaget i läroplanen började han med att slå fast att Sverige hade ett stort behov av avancerat tekniskt kunnande. Ett sådant kunde ligga till grund för industrins framtida export och arbetsmarknadens goda utveckling:

Sverige måste därför både idag och i framtiden värna om sin tekniska och naturvetenskapliga utbildning så att den utvecklas i takt med teknikens ständigt nya landvinningar. [...] Att teknik blivit ett obligatoriskt inslag i grundskolan måste dessutom ge vissa effekter. Inte minst tror jag att den obligatoriska undervisningen i teknik kan vara av betydelse för att få flickorna att i större utsträckning våga välja en teknisk eller naturvetenskaplig utbildning. ${ }^{396}$

Sverige hade en outnyttjad teknisk resurs i flickorna, konkluderade Orehag. Det var viktigt att ta tillvara på den.

I samma nummer av Pedagogiskt magazin kunde flera entusiastiska artiklar berätta att ämnet hade en kompenserande funktion för flickor. ${ }^{397}$ 
En av texterna handlade om positiva erfarenheter av enkönad undervisning på lågstadiet. För att inte de mer teknikvana pojkarna skulle störa undervisningen hade man skapat renodlade flickgrupper. Artikeln lyfte bland annat fram användandet av ett nytt undervisningsmaterial: "Med hjälp av stora, härliga mekanolådor tar de igen vad de har förlorat i sina småflicksliv." ${ }^{398}$ Den emancipatoriska tonen tycktes dock gälla i lika hög grad för den kvinnliga läraren. Hennes berättelse bekräftade vikten av ett rekryterande tilltal även till vuxna kvinnor: "Jag har varit lika ovan vid att tänka tekniskt som de flesta andra kvinnor. Och fortfarande är jag ingen expert, vare sig på teknik eller på teknikundervisning. Men jag fick en kick - på studiedagen på Tekniska Museet [...] - och sedan dess har jag tyckt att teknik är jätteroligt." 399

Samtidigt som artikeln om mekanolådorna skildrade teknikundervisning som frigörande kunde den också förstärka bilden av att traditionellt feminina attribut var ovanliga i teknikmiljöer. Författaren påtalade att "fyra flickor med långt, strömmande Lucia-hår dröjde sig kvar vid sina 'maskiner" trots att lektionen gick mot sitt slut. ${ }^{400}$ Läraren å sin sida hade "lockar runt huvudet, röda byxor, röda, vackra naglar och små veck på blusen runt halsen" ${ }^{401}$ Just könens olika erfarenheter av och relationer till ämnet kom $\mathrm{i}$ den framväxande debatten att aktualisera tanken på tekniken som någonting icke-neutralt. Snarare hade den i betydande grad formats och utvecklats av manliga behov och erfarenheter. Det gjorde dels att kvinnor kom längre ifrån en teknisk erfarenhet, dels att tekniken i flera fall utformades på ett sätt som var destruktivt och mindre socialt ansvarstagande. ${ }^{402}$

I förlängningen av diskussionen låg frågan om det var kvinnorna eller tekniken som behövde förändras. Som ett resultat växte tanken på kvinnlig teknik som annorlunda fram i diskussionen. ${ }^{403}$ Fredrika-Bremer-Förbundets tidskrift Hertha hade våren 1982 ett temanummer om "en ny mänskligare teknik". Uttrycket och resonemangen vilade på antagandet att det behövdes kvinnor i både teknisk utbildning och tekniska yrkesliv eftersom de tillförde något som saknades i det rådande klimatet. Ledaren talade om skillnader mellan den manliga och kvinnliga tekniken:

I vår iver att inte framstå som manshatare skaffar vi oss inte den makt och kraft som behövs för att förverkliga den kvinnliga principen: den som ger människor överlevnad, framtid. I förlängningen av den manliga destruktiva tekniken finns kärnvapenkrigets totala utplåning och vår ekologiska bankrutt. Vi måste få över fler män och kvinnor i vår 
färdriktning: för jämställdhet och överlevnad och för en teknik som ger LIV i stället för DÖD. ${ }^{404}$

Här utkristalliserades ytterligare ett argument för fler kvinnor inom tekniska yrken som var skilt från ekonomiska hänsynstaganden. Snarare var förändringen viktig för att fortlöpande kunna påverka tekniken som samhällsfenomen. Dessa tankar kom också till uttryck i Skolöverstyrelsens skrift Vill vi, så kan vi, så gör vi det! som utarbetades för att hjälpa lärare och lärarutbildare att rekrytera fler flickor till naturvetenskap och teknik. I den uttalade sig fysikern och samhällsdebattören Bodil Jönsson om de nya kvaliteter som fler kvinnliga ingenjörer skulle bibringa tekniken:

Vi har inte rätt att bara titta på hur flickornas studie- och yrkesval förutbestämmer dem till en framtida förödande kvinnoarbetslöshet. Vi har inte rätt att låta teknikutvecklingen bara rulla på som hittills skett. Vi måste faktiskt satsa på att få andra tekniker. Om inte rekryteringen ändras, så lär det också framöver bli en tredjedel som ägnar sig åt militärteknikutveckling, medan t ex vardagsteknik i kök, hem och sjukvård förblir lika eftersatt som nu. [...] De traditionellt kvinnliga dygderna (hos kvinnor och män) behövs på en central plats också inom tekniken. ${ }^{405}$

Tanken på teknikens behov av feminina värden kom också till uttryck i broschyren Tjejer på KTH som gavs ut i syfte att förändra antagningsmönstret till den manligt dominerade institutionen. I texten uttrycktes bland annat argumentet att fler kvinnor skulle kunna skapa en ny ingenjörs- och teknikerkultur där mjukare värden dominerade. Detta eftersom kvinnor var mer benägna att se de sociala aspekterna av tekniken. Huvudansvaret för hemmet och barnen gav kvinnor en erfarenhet som ställde andra krav på utformningen av ingenjörers kompetens i vardagen. Idén om kvinnan-som-ingenjör sattes även här samman med nya lösningar på tekniska problem. ${ }^{406}$

\section{Kvinnorna, tekniken och egenmakten}

När Lena Hjelm-Wallén berörde åtgärder mot teknikerbristen pekade hon också på kampanjen "Fler kvinnor till industrin" som hade inletts 1983 på initiativ av Arbetsmarknadsdepartementet. Regeringen hade i 
denna satsning anslagit tio miljoner kronor som fördelades på ett stort antal lokala projekt. Medlen kanaliserades främst genom de tekniska högskolorna, men också genom syokonsulenter och kvinnoförbund. ${ }^{407}$ Även om satsningen inte hade samma långsiktiga karaktär som grundskolans teknikämne fick den ändå mycket stor räckvidd. Regeringen beskrev själv det hela på följande sätt: "Genom kampanjen 'Fler kvinnor till industrin' har 46000 flickor/kvinnor på mer än 100 orter i landet berörts direkt av verksamheten. Förutom central och lokal projektledning har ca 3200 lärare, 3 ooo föräldrar, 800 företag och 600 skolor varit engagerade i arbetet." ${ }^{008}$ Även under några av de nästföljande åren betalades det ut stora summor för att hålla de igångsatta projekten verksamma. Genom informationsspridning, studiedagar, kurser och temaarbeten riktades kampanjer till framförallt flickor i högstadiets åttonde klass. ${ }^{409}$

"Fler kvinnor till industrin" var ytterligare ett exempel på hur fostran till jämställdhet och till teknikintresse växt samman som politiska målsättningar. I flera avseenden var kampanjen ett förverkligande av de linjer om studie- och yrkesrådgivning som Skolöverstyrelsen ett decennium tidigare dragit upp i skriften Ett friare val. Strävan efter att flickor skulle frigöra sig från stereotyper kunde motivera en ökad obalans i information, rådgivning och propaganda.

Bland de många lokala projekt som utarbetades fanns ett flertal som förde unga flickor i kontakt med förebilder som hade valt teknik, både i form av äldre elever och vuxna kvinnor i yrkeslivet. Ett exempel på det förstnämnda var Munkbroskolan i Bohuslän som bedömdes ha lyckats mycket väl med att rekrytera yngre elever. Tidigare hade få flickor valt tillvalsämnet teknik på högstadiet. I mellanstadiets årskurs sex hade man därför genomfört en kampanj med resultatet att många fler nu valde detta ämne. Dessa så kallade "teknikflickor" fick senare uppdraget att repetera förfarandet då nya mellanstadieelever bjöds in till att medverka vid undervisningen. Genom att ge information till de yngre och låta dem stifta bekantskap med föremål som hade skapats på lektionerna - till exempel radioapparater och svävare - verkade "teknikflickorna" som förebilder. ${ }^{410}$

Som besökande rollmodeller i skolorna fanns också kvinnor från industrisektorn, så kallade "brytare", som företrädde otraditionella val. I olika konstellationer representerade de yrken som plåtslagare, elektriker, datakonsulter eller svetsare. ${ }^{411}$ Dessa typer av arrangerade möten med teknik var avsedda att överföra kunskap och förtrogenhet i såväl fysiskt som konceptuellt avseende. Men i minst lika hög grad skulle de överföra 
beteenden. I en uppföljning av "Fler kvinnor till industrin" betonades betydelsen av att påverka attityder genom att möta flickorna direkt:

Det bästa sättet att få flickorna att ändra sitt beteende är givetvis att påverka dem. Att skapa medvetenhet och utveckla förståelse hos flickorna görs enklast i samverkan med dem. Flickorna i den här åldern är fortfarande okunniga om arbetsmarknadsfrågor och står samtidigt inför viktiga val inför sin framtid. Däremot är det inte säkert att fördomar och traditionsbundenhet är lika starka som hos vuxna. Det är således lättare att nå snabba resultat genom aktiviteter med flickorna direkt. ${ }^{412}$

Bland utvärderingarna var det vanligt med rapporter som kunde berätta om framgång och förändrade attityder till teknik. Det gällde exempelvis för de sommarkurser som Skolöverstyrelsen anordnade i mitten av 1980-talet för 3 000-5 000 flickor varje år. Undervisningen blandade yrkesteori, studiebesök och praktiska moment som svetsning, fräsning och lödning. I summeringar av sommarkurserna framkom att många flickor började se annorlunda på teknik som samhällsfenomen och betrakta det som ett tänkbart studie- och yrkesval. ${ }^{413}$

De olika initiativen kan i ett avseende betraktas som åtgärdsprogram $i$ syfte att - via flickornas växande självförtroende och förtrogenhet - leda till ett slags makttagande över tekniken. Men i detta främjade programmen också ett subjektets makttagande över reformeringen till en önskvärd medborgare ur ett samhälleligt perspektiv. Som sociologen Mitchell Dean har påpekat har utvecklandet av program för ökad egenmakt - det som med engelskans svåröversättliga term benämns empowerment - ofta inbegripit en kombination av deltagande och självbestämmande i liberala demokratier under efterkrigstiden:

It suggests that the value of political arrangements can be measured by the degree to which they enable all citizens to participate in decision making processes. Empowerment is, in this sense, the normative correlate of the explanatory focus on agency. If human beings are, at least potentially, agents, then they need to be empowered to become so. Programs of empowerment are particularly clear examples of those contemporary liberal rationalities of government that endeavor to operationalize the self-governing capacities of the governed in the pursuit of governmental objectives. ${ }^{414}$ 
Flickorna som blev föremål för Arbetsmarknadsdepartementets och Skolöverstyrelsens kampanjer gavs genom det fysiska och intellektuella makttagandet över tekniken även en stor delaktighet i omskapandet av sig själva. De som tog ett otraditionellt beslut blev "tekniktjejer". Därigenom uppfyllde de också ett av rekryteringspolitikens främsta mål.

\section{"Ställ upp för din dotter" - med familjen som grund för självstyre}

De könsspecifika tilltalen skulle mångfaldigas i takt med att floran av åtgärder för teknikerrekrytering växte kraftigt under 1980-talet. Aktörerna som framträdde var också fler än vad som rymdes inom statliga kampanjer och skolmiljöer. I slutet av 1970-talet bildade Fredrika-Bremer-Förbundet en Kvinnor och teknikgrupp i syfte att förbättra flickors möjligheter att välja och arbeta inom tekniska yrken. Tillsammans med Civilingenjörsförbundet och tidningen $N y$ Teknik anordnades under ett antal år Kvinnor och teknikveckor på Tekniska museet. Evenemanget samlade flera hundra deltagare som företrädde studie- och yrkesvägledning, tekniska utbildningar och arbetsförmedlingar. Dessutom deltog representanter från de nordiska grannländerna. ${ }^{415}$

Kvinnor och teknikveckan fick stor medial uppmärksamhet och inspirerade till flera regionala projekt i övriga delar av landet. I bland annat Luleå, Söderhamn, Västerås och Eskilstuna arrangerades studiebesök, utställningar, demonstrationer och torgmöten på temat "kvinnor och teknik" ${ }^{416}$ Som en konsekvens etablerades lokala nätverk för nya rekryteringspraktiker. Även här tecknades en sammansatt behovsbild där varningar om en hårdnande jobbsituation och kvinnors risk att hamna utanför en framtida teknisk arbetsmarknad kombinerades med påminnelser om hur viktig frågan om det totala antalet ingenjörer var för landets industri och ekonomi. ${ }^{417}$

Fredrika-Bremer-Förbundet anordnade också offentliga utställningar i samband med Kvinnor och teknikveckorna. År 1984 bjöd man in till ett arrangemang på Tekniska museet med rubriken ”Tekniken i praktiken - ställ upp med din dotter, ta med dig din mamma". Som titeln angav vände sig förbundet till flera generationer samtidigt och sökte få unga och vuxna kvinnor att tillsammans besöka utställningen. Inbjudan innehöll uppmuntrande paroller som "Kom, experimentera och reparera", men kunde också försäkra om bistånd vid behov: "Kunniga handledare 
hjälper till." ${ }^{18}$ Programmet bestod av konkreta punkter för ett aktivt deltagande som bilreparation och cykelpunka, datorer och amatörradio, men även information om kvinnliga utövare av typiskt manliga yrken. Under rubriken "Kvinnliga piloter - finns dom?" och "Dra till skogen tjejer - kvinnliga skogsmästare berättar" framträdde kvinnor som hade gjort ovanliga yrkesval. ${ }^{419}$

Evenemanget blev en stor publikframgång och Tekniska museet noterade en av sina högsta besökssiffror på länge. ${ }^{420}$ Även studie- och yrkesvägledare fanns på plats i utställningen och informerade under rubriken "Fler flickor till teknisk utbildning". Deras närvaro underströk att syoorganisationens förhållande till rekryteringspolitiken var mångbottnad. När det handlade om vägledning inför naturvetenskapliga studier hade konsulenterna reagerat på den övertalande tonen ett decennium tidigare. Av denna kritik syntes nu inte mycket. Istället skulle de i flera olika sammanhang under 1980-talet bidra till att föra ut budskapet om ingenjörsyrket till flickor. Idén om den kompensatoriska propagandan befäste därmed sitt inflytande över rådgivning $\mathrm{i}$ anslutning till val av utbildning och yrke. ${ }^{421}$

Strategin att tilltala två generationer samtidigt utgick från att det fanns en större och mer blandad publik för budskapet om kvinnor och teknik. Utställningen "Tekniken i praktiken” bjöd således in åskådarna att delta och sökte samtidigt upprätta relationer med dem. Den enskilde individen pålades - som mor eller dotter - ett ansvar för sin egen och andras utveckling. Medievetaren Ylva Habel har visat på en liknande responsibilisering i tilltalet till barn och i förlängningen deras föräldrar i den mjölkpropaganda som bedrevs i Sverige under mellankrigstiden. ${ }^{422} \mathrm{I}$ likhet med kallelsen att delta i det hälsobringande mjölkdrickandet hade informationen under Kvinnor och teknikveckan syftet att förmå individer att reflektera över och förbättra sig själva i enlighet med samhälleligt definierade mål. De båda evenemangen är även exempel på att det privata och ofta mer slutna familjeområdet kunde öppnas upp för upplysande och reformerande aktiviteter.

Det breda tilltalet till familjen kan också sägas tydliggöra rekryteringsfrågans roll i ett större befolkningspolitiskt perspektiv med tanke på att det riktade sig till flera generationer samtidigt. Att närma sig de vuxna var en prioriterad verksamhet inte bara för arrangemanget på Tekniska museet; regeringen hade varit noga med att nämna de uppskattningsvis 3 ooo föräldrar som nåtts av kampanjen "Fler kvinnor till industrin". I Sydsvenska Dagbladet vände sig Bodil Jönsson 1983 i en specifik vädjan till 


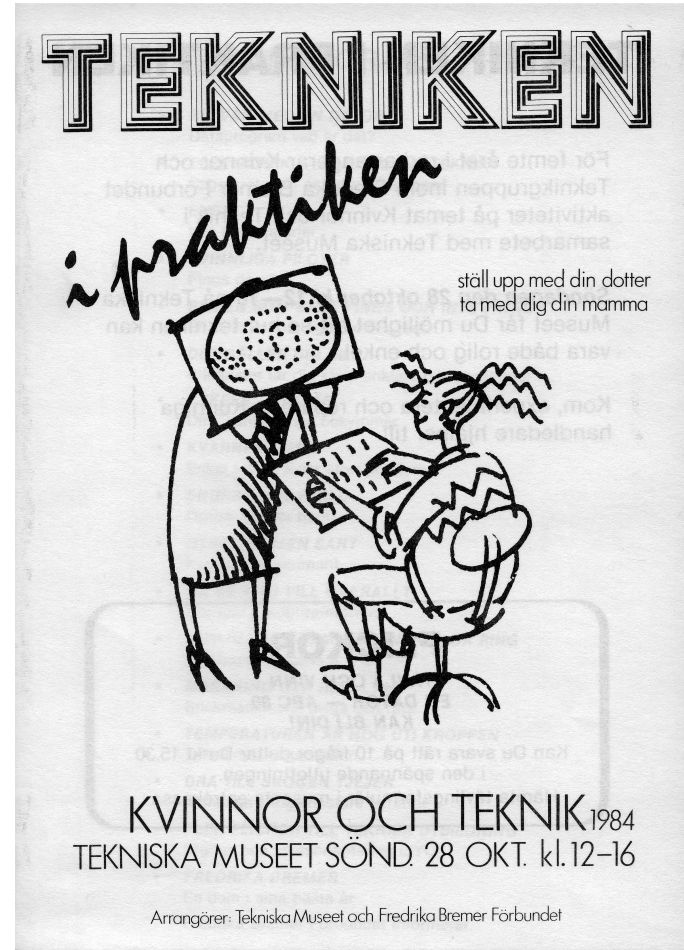

Bild 15. Programfolder från utställningen "Tekniken i praktiken” på Tekniska museet hösten 1984. Budskapet riktades till både den yngre och den äldre generationen. (Bildkälla: Tekniska museet)

mödrar och fäder och underströk hur viktigt det var att de uppmuntrade sina döttrar i valet av teknik:

En åtminstonebön till Dig som förälder: Om Din flicka kommer hem och säger att hon funderar på att välja 2-4 årig teknisk gymnasieinriktning, försök då att ÅTMINSTONE inte hindra henne! Egentligen borde Du förstås istället stötta henne och önska henne lycka till - har Du tänkt på hur viktigt hennes val kan bli för henne själv och andra? ${ }^{423}$

Jönssons uppmaning placerade de vuxna i centrum för teknikpropagandans positiva maktutövningsformer - att underlätta önskvärda handlingar och beteenden.

Fredrika-Bremer-Förbundets strävan att nå familjen begränsade sig inte 
till utställningar. Adresserandet av mamma-dotter gjordes också genom andra kanaler för påverkan. Foldern "Ställ upp för din dotter" spreds i 13 ooo exemplar under 1984. I den var argumenten mer renodlat jämställdhetspolitiska; för att deras döttrar skulle få ett yrke som inte riskerade att leda till arbetslöshet, deltidsarbete eller låg lön uppmuntrades föräldrarna att stödja dem i valet av en teknisk bana. Den enskilda kvinnans väl, inte nationens eller ekonomins, var grunden för tilltalet. I bilder, statistik och korta texter förmedlade den utskickade foldern hur ansvarstagande det var att bryta könsmönstret: "Flickorna måste välja också bland de tekniska utbildningsvägarna om de skall få jobb i framtiden. Förälder! Väljer din dotter arbetslöshet eller jobb? Ge henne stöd för ett klokt val."224 Propagandamaterialet ingick i projektet TUFF (Tekniken, Utbildningen, Flickorna, Förälder!) som drevs av förbundets lokala kretsar. I dessa sammanhang ingick också föräldramöten, annonser och studiedagar med information om könsstereotypa val och familjens betydelse för individens framtida yrke. ${ }^{425}$

\section{Teknikrekryteringen och självstyrets offentlighet}

Ett mått på den ökade räckvidden för frågan om flickor och teknik var att den engagerade två organisationer med så olika bakgrund som Fredrika-Bremer-Förbundet och Civilingenjörsförbundet. Det senare hade redan under 1970-talet identifierat tekniska utbildningar och yrken som viktiga strävansmål för kvinnor. ${ }^{426}$ Under den första halvan av 1980-talet var förbundet mycket aktivt i rekryteringsfrågan, bland annat genom utgivningen av skriften Ungdom och teknik som utkom i två upplagor och innehöll ett stort antal genomförda och framåtblickande idéer. Civilingenjörsförbundets kontakter med de tekniska högskolorna och industrin gav ytterligare spridning åt aktiviteterna och bildade nätverk för de gemensamma ambitionerna. Förbundet deltog också i uppvaktningar av Utbildningsdepartemetet och Arbetsmarknadsdepartementet för att förmå dem att ge frågan om kvinnor och teknik större genomslag. ${ }^{427}$

Ett av de mer medialt framträdande initiativen var en presskampanj med titeln "Beställ en intervju med en kvinnlig civilingenjör!" På förtryckta vykort uppmanades lokaltidningar att skicka in sina uppgifter och invänta bakgrundsmaterial och kontaktinformation med möjlighet att ringa upp för ett samtal. ${ }^{428}$ De intervjuer tidningarna genomförde spred budskapet om kvinnliga förebilder ut till en allmänhet som bestod av både ungdomar och vuxna. Andra vykort vände sig direkt till skolorna och deras 


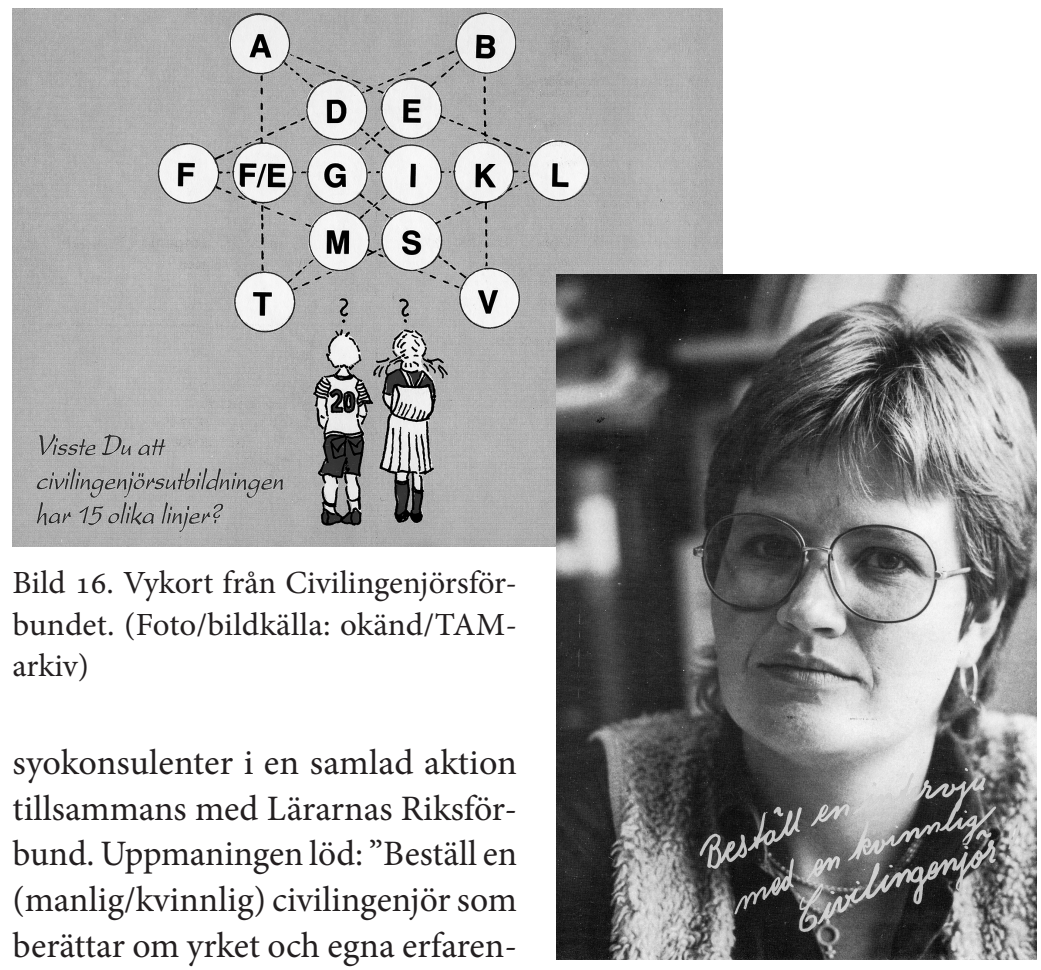
heter till Din skola!" 429

Kampanjerna från Civilingenjörsförbundet var resurskrävande och noga planerade åtgärder. Att de distribuerades med post skapade möjligheter att nå en stor publik i hela landet. En mer resurssnål form av propaganda, men som ändå kännetecknades av personliga tilltal, var ett samarbete om "telefonjourer" mellan studievägledare vid de tekniska högskolorna och vissa kommuner. I informationsfoldrar från exempelvis Nacka kommun fanns bilder på tjejer i gymnasiet som valt tekniska utbildningar. Foldrarna talade direkt till de elever som ännu inte gjort sitt val och uppmanade dem att "ta chansen att prata med någon som går på en utbildning med inriktning mot teknik eller naturvetenskap" ${ }^{430}$ Telefonjourerna framstod som kostnadseffektiva. Men förutom att de var billiga var de också arrangerade för att skapa otvungna möten mellan personer i liknande åldrar. Christina Sternerup, syokonsulent på KTH, poängterade den psykologiska mekanism som kunde uppstå: "Denna syo-information som ges elever emellan är mycket effektiv. Man 'litar' mer på en jämnårig förebild, som faktiskt själv gjort ett otraditionellt val, än på t ex syokonsulenter, lärare och föräldrar."331 

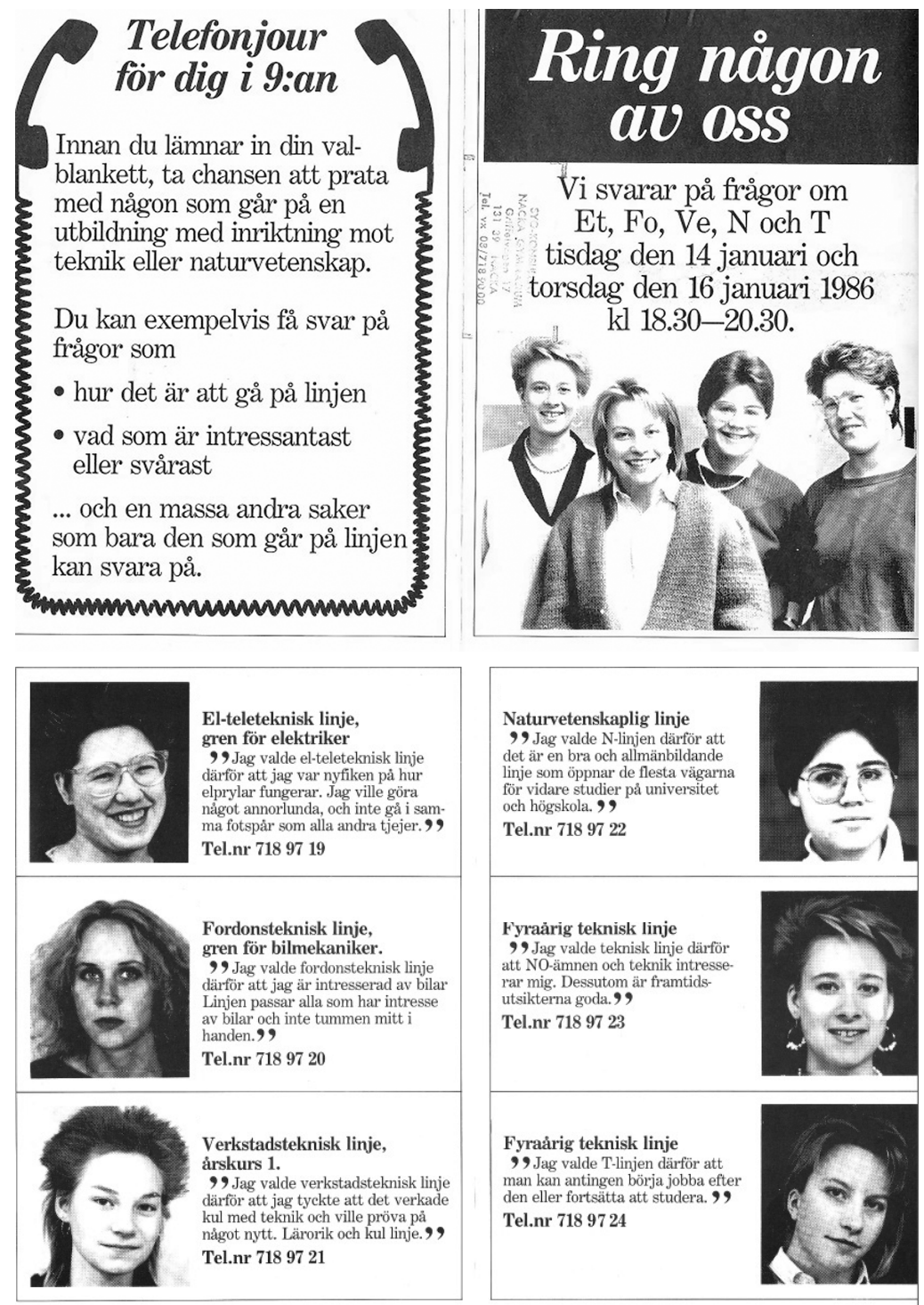

Bild 17. Reklam för telefonjourer, Nacka kommun. (Foto: okänd/Sternerup, 1987)

Texterna och bilderna från telefonjouren kan också betraktas som ett uttryck för genomgångna subjektiveringsprocesser. Annorlunda uttryckt visade foldern från Nacka kommun att rekryteringspolitiken hade omsatts i självteknologier genom att understryka hur de porträtterade flickorna hade 
tagit till sig budskapet om tekniken och gjort det till sitt. Telefonnumren till de olika personerna ackompanjerades av berättelser om varför just de valt $\mathrm{N}$-linjen, T-linjen, verkstadslinjen eller el-teleteknisk linje. ${ }^{432}$

De subjektsskapande processerna var på en gång individuella och kollektiva, eftersom de rörde både personliga preferenser och könsbundna villkor. En flicka berättade att hon valde el-teleteknisk linje för att hon "var nyfiken på hur el-prylar fungerar" och "ville göra något annorlunda och inte gå i samma fotspår som alla andra tjejer". ${ }^{433}$ En annan hade valt fordonsteknisk för att hon var "intresserad av bilar". Hon kunde också berätta att den passade alla som delade hennes håg för fordon och inte hade "tummen mitt i handen". ${ }^{34}$ De andra personernas berättelser återgav idén om N-linjens breda behörighetsgrundande karaktär och att T-linjen gav möjlighet till jobb direkt efter gymnasiet. Det skulle ge dem en god möjlighet att läsa vidare eller att gå ut direkt till en ljus arbetsmarknad.

Uppmaningen att ringa till telefonjourerna och prata om teknik och naturvetenskap ingick i en kedja av självteknologier. Flickorna på bilderna illustrerade det redan skedda, medan tilltalet till alla andra verkade för det planerade och önskvärda. Även om skälen att välja dessa utbildningar bara var några rader långa, bekräftade foldrarna från Nacka kommun på många sätt de motiv som Utbildningsdepartementet, näringslivet och Fredrika-Bremer-Förbundet anfört för att flickor skulle välja att bli ingenjörer och naturvetare.

Samma modell återkom i andra material där bakgrunden till flickors val gavs mer text- och bildmässigt utrymme. I broschyren Tjejer på KTH var livsberättelser om teknikval en del i exponerandet av förebilder. De utvalda individerna representerade tillsammans olika vägar till ingenjörsyrket. Många av dem berättade att de varit teknikintresserade i hela sitt liv. Ingrid som läste farkostteknik skrev: "När jag var sex-sju år och folk frågade mig vad jag skulle bli när jag blev stor, svarade jag tvärsäkert: INGENJÖR! [...] På gymnasiet tyckte jag mycket om det mesta av matten, fysiken och teknologin och jag visste att jag ville vidare inom dessa områden." ${ }^{435}$ Hennes namne som läste kemiteknik gav en liknande bild:

Så långt tillbaka jag kommer ihåg har jag alltid varit intresserad av matematik, fysik och kemi. Valet av teknik blev därför ganska naturligt. I gymnasiet hade jag dessutom en bra lärare i kemi som väckte mitt intresse för ämnet. KTH valde jag därför att det ligger nära min uppväxtort och antagligen också på grund av en viss påverkan hemifrån. Både min pappa och bror har gått här. ${ }^{436}$ 
De unga kvinnornas berättelser visade att det var möjligt att tidigt vänja sig vid en självuppfattning som ingenjör. Men här fanns också de som kunde berätta om den rakt motsatta bilden. Eva som läste lantmäteriutbildningen förklarade:

Om nån hade sagt till mej när jag gick i gymnasiet i Östersund, att jag om några år skulle gå på Tekniska Högskolan i Stockholm, skulle jag ha utbrustit i ett stort ALDRIG I LIVET! Teknik och KTH var fjärran för mej. Jag hade överhuvudtaget inte tänkt i de banorna. Men hur det var fick jag en broschyr om tekniska linjer i min hand och började läsa. ${ }^{437}$

Trots att de olika narrativen hade individuella inslag förenades de i skapandet av en offentlighet åt internaliseringen av rekryteringspolitikens budskap. Övertagandet och återberättandet av enrolleringens argument i tryckt propaganda gav på så sätt ytterligare en dimension åt den attitydpåverkan som olika avsändare avsåg att åstadkomma. Som goda exempel var de unga kvinnorna utvalda och exponerade för att ge ett ansikte och en röst åt det möjliga i att tjejer valde teknik.

Det så kallade N-projektet tillkom på initiativ av Svenska Arbetsgivareföreningen, Kungliga Tekniska högskolan och Åsö vuxengymnasium för att frambringa fler kvinnliga gymnasieingenjörer under ett antal år i mitten av 1980-talet. Strategin var att få flickor som gick på naturvetenskaplig linje i Storstockholmsområdet att gå över till fyraårig teknisk linje genom att locka med praktikplatser och goda möjligheter till jobb efter gymnasiet. ${ }^{438}$

I boken High Tech Ladies som gavs ut ett antal år senare följdes flera av N-projektets deltagare upp i varsitt kort kapitel. Boken vände sig till flickor på olika skolnivåer, studie- och yrkesrådgivare samt rekryteringsansvariga på företag. I inledningen slog författaren fast: "Bättre reklam för en teknisk utbildning än de här kvinnornas beskrivning av sina jobb och arbetsförhållanden går knappast att fă." ${ }^{339}$ Kapitlen innehöll många exempel på kvinnornas internalisering av budskapet att de borde välja teknik som utbildning, yrke och identitet. Flera av dem skildrade hur roligt och givande men också krävande det var att läsa till ingenjör. Inte minst bekräftade de den stora roll som engagerade syokonsulenter hade spelat för att de skulle våga ta ett otraditionellt beslut. ${ }^{40}$

En av de mer aktiva spridarna av ingenjörspropaganda för flickor var 


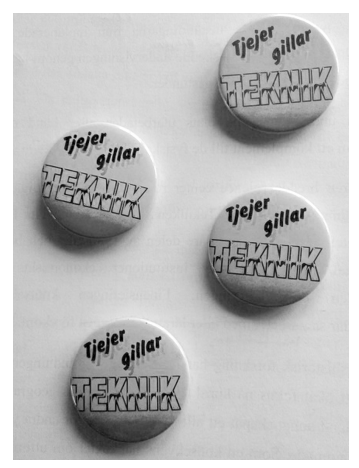

Bild 18. Broschyrer, knappar och klistermärken från KTH:s studie- och yrkesvägledande verksamhet. Akronymen KTH hade omtolkats till "Kvinnor, Teknik, Högskola”. (Bildkälla: i författarens ägo/Klevard \& Wiklund)
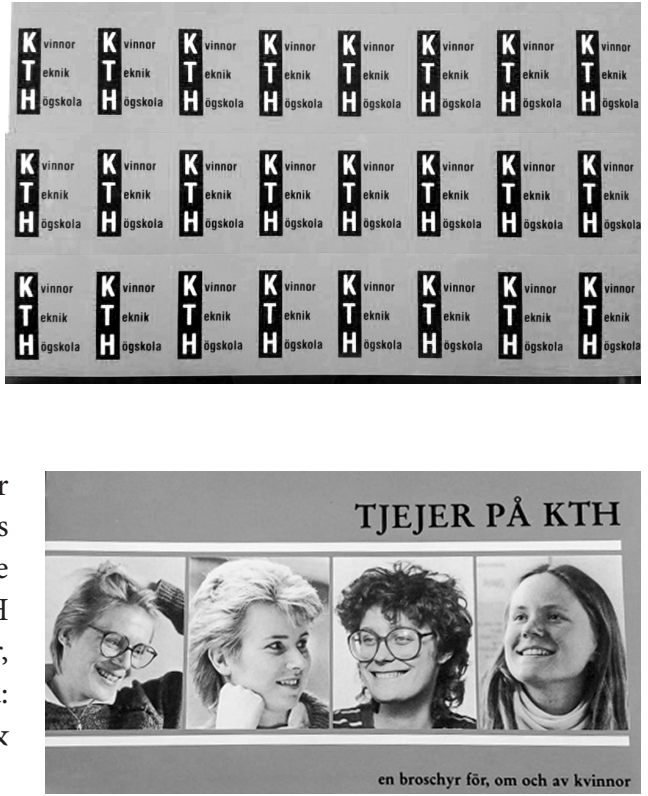

KTH som vid mitten av 1980-talet bedrev ett omfattande arbete framförallt i huvudstadsområdet. Förutom att propagera för N-projektet anordnade högskolan bland annat kurser i allmän databehandling för högstadieflickor samt utarbetade stora mängder material för studie- och yrkesvägledare. ${ }^{441}$ På återkommande ”Tjejkvällar” för flickor i gymnasiets avgångsklasser berättade kvinnliga studenter på KTH om förtjänsterna med sitt studieval. Att förebilderna framträdde kroppsligen skänkte ytterligare en dimension åt subjektiveringsprocessens offentlighet. ${ }^{442}$

\section{Science center-rörelsen mellan fritid och yrkesval}

Genomförandet av Kvinnor och teknik-veckan i Stockholm hade understrukit museivärlden som en institution där olika aktörer sökte nya vägar för att öka ungdomars kontakt med naturvetenskap och teknik. Ur ett styrningsperspektiv var sådana platser inbegripna i tydliga rekryteringspolitiska processer med avseende på självstyre och identitetsformering. Arrangemangen inkorporerade vitt skilda delar av samhället, men kan ändå sägas ha verkat som en utlöpare av planerade och i flera fall noga orkestrerade liberala påverkansstrategier. 
Sådana typer av strategier var inte begränsade till en nationell kontext. I den monumentala byggnaden The Palace of Fine Arts i San Francisco hade portarna 1969 öppnats till The Exploratorium - en institution som kallade sig museum för "vetenskap, konst och mänsklig iakttagelse". ${ }^{43}$ Huvudsyftet sades vara att sprida naturvetenskap och teknik till allmänheten och till barn och ungdomar i synnerhet. I denna ambition anslöt sig museet till den breda rörelse som i samtiden växte fram under beteckningen "public understanding of science and technology" eller "scientific literacy". ${ }^{44}$ I motsats till traditionella vetenskapsmuseer hade The Exploratorium beslutat att undvika att presentera äldre föremål och objekt som inte fick vidröras av besökarna. Istället skulle publiken på en yta av drygt 8 ooo kvadratmeter mötas av samtida skapelser och upplevelser som förmedlade vetenskap på ett interaktivt sätt. ${ }^{445}$

Trots sitt fokus på samtiden hade The Exploratorium sökt plats för sina utställningar i en lokal i äldre stil. The Palace of Fine Arts uppfördes ursprungligen i samband med världsutställningen i San Francisco 1915. Under 1960-talet hade byggnaden renoverats och förstärkts med mer tåliga byggnadsmaterial för att permanentas som institution. ${ }^{446}$ Samma år som The Exploratorium öppnade för allmänheten invigdes ett liknande museum i Kanada kallat Ontario Science Centre. Det var inrymt i en helt ny byggnad som bestod av tre sektioner som bands samman av inglasade broar, en arkitektonisk stil som markerade ytterligare ett led i det vetenskapliga museets transformering. The Exploratorium och Ontario Science Centre blev, trots sina skilda fasader, snabbt stilbildande för en omförhandling av museernas inriktning och publika uppdrag. Under 1970-talet var tillväxten av liknande institutioner oerhörd. Många av dem valde att markera avstånd från den äldre museikulturen och ett betungande historiskt arv genom att kalla sig just science center. Mätt i antalet besökare var de en enorm framgång - mellan 1973 och 1975 ökade siffrorna i USA från drygt 14 till 36,5 miljoner personer. ${ }^{447}$

Science center-rörelsens snabba tillväxt förstärkte närvaron av naturvetenskapligt och tekniskt utbildande verksamheter i det amerikanska samhället. Varje ny byggnad som uppfördes underströk också att expansionen skedde utanför skolans traditionella domäner. Den utvecklingen var inte begränsad vare sig till USA eller till museivärlden. Ökningen av antalet naturvetenskapliga och tekniska fritidsaktiviteter för ungdomar hade under 1900-talet bildat en global trend. Efter andra världskriget steg ambitionsnivån ytterligare för dessa verksamheter som i internationella 
sammanhang ofta kategoriserades under benämningen out-of-school science education. Termen hade fått ökad spridning under 1950- och 1960-talen genom de överstatliga sammanhang där skolans naturvetenskapliga ämnen prioriterades högt. Vi har redan tidigare berört OECD och NATO som exempel på sådana organisationer. I en skrift utgiven av FN-organet Unesco definierades termen som:

educational activities undertaken or done outside the formal teaching periods and the formal curriculum. An activity is "out-of school" even if it takes place within the framework of the school; and even if it takes place in a free activity period in what is normally part of the school working day. ${ }^{48}$

De aktiviteter som främst rekommenderades av Unesco var vetenskapliga museer, föreningar, läger, utställningar och tävlingar. Aktiviteterna riktade sig till yngre barn, men också till dem som stod i begrepp att göra sina val inför högre studier. På så sätt bildade de kanaler mellan formella och informella praktiker för lärande och identitetsskapande inom dessa ämnen. Skolorna förutsattes ofta vara delaktiga på ett eller annat sätt. Antingen kunde de bistå med lokaler eller också med entusiastiska lärare som deltog på sin fritid. Med tiden knöts fenomenet till ett alltmer globalt definierat rekryteringsbehov och termen out-of-school science education kom att beteckna lika mycket en politisk strävan som en uppsättning olika aktivitetsformer. ${ }^{449}$

Även i Sverige blev nya verksamheter för att utöka ungdomars kontakt med vetenskap och teknik allt vanligare och mer omfattande. Återstoden av det här kapitlet kommer jag att ägna åt framväxten av sådana inslag och deras roll inom rekryteringspolitiken. Låt oss emellertid först återvända till San Francisco och formandet av science center-rörelsens utgångspunkter.

Initiativtagaren till The Exploratorium, fysikern Frank Oppenheimer, grundade sin verksamhet i en kritik av den befintliga utbildningen inom naturvetenskap. I likhet med många samtida röster menade han att den experimentella traditionen inte var tillräckligt representerad i skolornas undervisning. Under en tid verkade han inom de nyorienterande kursplaneprojekten PSSC och ESS ("Elementary Science Study") men valde senare att istället utveckla tanken på utställningar. ${ }^{450}$ Även inom museivärlden hade man efter Sputniks uppskjutande börjat ställa nya frågor om hur man på ett fruktbart sätt kunde utveckla sin roll som förmedlare av vetenskaplig 
kunskap. Oppenheimer deltog i dessa diskussioner tillsammans med andra nytänkare vilkas idéer både fascinerade och väckte undran bland kollegorna om hur långt ett museum kunde gå i sin förändringsiver och sin önskan att komplettera skolornas funktion. ${ }^{451}$

Verksamheten i The Exploratorium byggdes dock inte upp som en motrörelse mot skolan, utan var avsedd att fungera i samarbete med den. Museet tog på sig uppgiften att skapa nya förutsättningar för lärande som skolsystemet inte kunde tillhandahålla. Efter hand växte det fram ett nära utbyte och såväl lärarfortbildningar som regelrätt elevundervisning hölls i byggnaden. Anpassningen verkade emellertid i båda riktningar - utställningarna iscensattes också efter innehållet i läroplanerna. ${ }^{452}$

Oppenheimers pedagogiska vision för museet innebar att han sökte öka allmänhetens intresse för naturvetenskap och teknik med hjälp av interaktivitet. Utifrån begreppet "sightseeing" ville han ge besökarna möjligheten att skåda naturens inre delar, vilka framställdes som oåtkomliga utan lämpliga instrument och specifika miljöer för observation. The Exploratorium utformades därför för att erbjuda en laborativ atmosfär där utställningarna förde besökaren i fysisk närkontakt med naturvetenskap. ${ }^{453}$ Målet var ett väsentligt ökat lärande, framförallt i jämförelse med de medieformer som bara medgav passivt iakttagande. Dessa antogs vara för begränsade i sin didaktik:

Classrooms and even television films afford severely limited possibilities for showing these sights. Sightseeing through these media resembles sightings from the windows of trains that are unstoppable, irreversible, and dominated more by the smells, sounds, and motions of the train than by the landscape. Sightseeing is invariably unsatisfactory where the main concern is a rush toward a destination or a need to catch the next train. The best kind of sightseeing involves some exploration and the freedom to decide what not to investigate and where to linger. The more one can become involved with the sights through touching, feeling, smelling, and activity, the more rewarding it can be. ${ }^{454}$

Även om The Exploratorium och Ontario Science Centre sökte markera avstånd från tidigare institutioner genom att endast inrikta sig på samtida utställningar, förvaltade de båda ett institutionellt och idémässigt arv. Tanken på att vetenskapliga museer kunde vara ett komplement till undervisningen i botanik och zoologi var fast rotad i 1800 -talets naturhistoriska 
museitradition. I Sverige var skolelevers rundvandringar bland utställda djur och växter ofta utformade som didaktiska utflykter, avsedda att åskådliggöra systematikens idé utöver vad läroböckerna kunde erbjuda. ${ }^{455}$

Inte heller den interaktiva utställningen var Oppenheimers skapelse. På resor i Europa hade han kommit i kontakt med fysiskt engagerande presentationer vid Deutsches Museum i München och Palais de la Découverte i Paris. Mötena gav en färdriktning för hans kommande projekt. Båda museerna var exempel på vetenskapliga institutioner som hade utvecklats under den första halvan av 1900-talet. Deutsches Museum skilde sig redan när det öppnade 1903 från andra museer genom att - vid sidan av äldre föremål - ställa ut modern naturvetenskap och teknik. Dessutom fick besökarna möjligheten att röra vid föremålen och pröva på att använda dem. Till en början var museet endast avsett för vuxna men det lockade inom kort också skolor. ${ }^{456}$ Palais de la Découverte, som öppnade 1937 , utmärkte sig genom att alla utställningar hade utformats för att skildra modern vetenskap och teknik. Vid utställningarna vägleddes besökarna av guider som förklarade och utförde experiment framför åskådarna. Institutionen valde också att inte kalla sig museum, och bröt sig därmed ut ur en mångårig tradition. ${ }^{457}$

\section{Deltagandets didaktik, deltagandets politik}

Arrangemangen i Palace of Fine Arts förde därmed på flera sätt vidare en historiskt rotad praktik med avsikten att aktivera besökarna. Publiken vid The Exploratorium gjordes ofta till deltagare i utställningarna. Exempelvis fick de möjlighet att ingående studera processer i ögat samtidigt som de pågick. Genom att utsättas för synvillor och andra optiska fenomen kunde de få insikt i relationen mellan ögat och hjärnan. I studiet av visuella processer blev besökarna således både forskare och forskningsobjekt vid samma tillfälle. ${ }^{458}$

En av de personer som bidrog till att torgföra science center-rörelsen under 1970-talet var Victor Danilov, föreståndare för Museum of Science and Industry i Chicago. I artiklar och böcker och i sin roll som ordförande för den rikstäckande organisationen Association of Science-Technology Centers utvecklade Danilov tankarna om deltagandetekniker. Besökare kunde aktiveras genom att fysiskt involveras i demonstrationsexperiment eller uppträdanden, men också genom frågor-och-svar-lekar som stimulerade viljan att föra experimentet vidare. Den amerikanska utvecklingen 
betraktade Danilov som en förlängning av de europeiska pionjärinsatserna under 1900-talets första hälft. Vid de stilbildande museerna i München och Paris hade revolutionen inom utställningsfilosofin en gång tagit sin början. I byggandet av de moderna institutionerna i Nordamerika, menade Danilov, hade man ytterligare utvecklat deltagandet som en väg för lärande av naturvetenskap och teknik. ${ }^{459}$

Det var dock uppenbart att de olika deltagandeformer som Oppenheimer, Danilov och deras efterföljare utvecklade drevs av en sammansatt motivbild utan tydliga rågångar mellan kunskapsförmedlande målsättningar och mer politiska ambitioner. I individens fysiska närvaro och engagemang vid olika utställningar och stationer investerades förhoppningar om ett lärande som på en och samma gång var både bildande och emancipatoriskt. Deltagandet skulle generera kännedom om och samtidigt resultera i ett mer aktivt förhållande till vetenskapen. ${ }^{460}$

Även med avseende på ovanstående dimensioner stod science centerrörelsen som en förvaltare av nedärvda tillvägagångssätt. Vetenskaps- och mediehistoriskt orienterad forskning om medverkande publiker under 1800- och 1900-talen har pekat på att involverandet av åskådare vid exempelvis museer och tillfälliga utställningar ofta ägde rum genom en deltagandets didaktik i diversifierade former. I mer eller mindre sofistikerade utföranden skapade detta specifika förutsättningar för kommunikation, påverkan och självstyre. ${ }^{461}$

Men även om närvaron av traditioner var uppenbar är det möjligt att argumentera för att delaktighetens politiska ambitioner hade skarpare konturer vid museer som The Exploratorium och Ontario Science Centre än i många av de publikaktiverande verksamheter som hade tillkommit under seklets första hälft. Rekryteringspolitikens framväxt under efterkrigstiden innebar en tydligare koppling till specifika värden - teknisk kapacitet, ekonomisk tillväxt, en fungerande arbetsmarknad och större jämställdhet - än de mer vaga ideal om vetenskapligt medborgarskap som många verksamheter en gång hade syftat till att främja. ${ }^{462}$

Spridningen av science center-rörelsen skulle därför inte endast innebära en allmän ökning av naturvetenskapligt och tekniskt utbildande verksamheter i samhället. I den expansionen byggde man också in rekryteringen som idé och praktik. Under 1970- och 1980-talen importerades de nordamerikanska utställningarna till Europa och blev starkt stilbildande. Därmed återvände det vetenskapliga museet till sin ursprungsplats, i en annorlunda form men med många bärande traditioner kvar. ${ }^{463}$ 


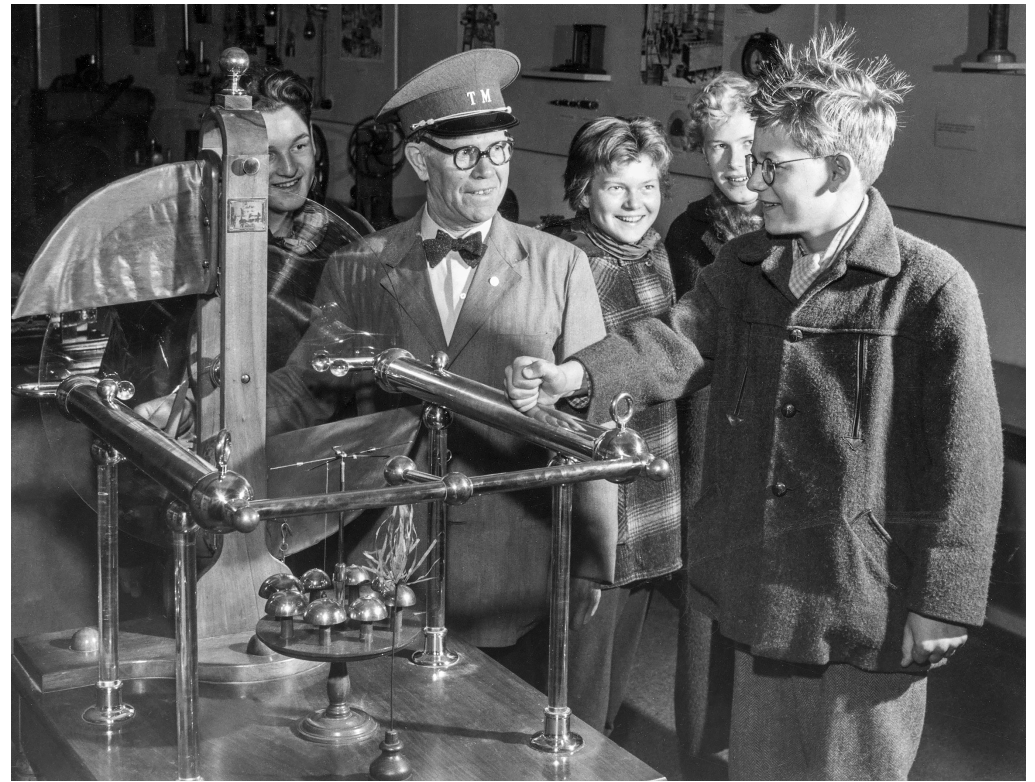

Bild 19. Influensmaskin förevisas i maskinhallen på Tekniska museet 1954. (Foto: okänd/Tekniska museet)

\section{Teknik- och naturvetenskapscentra i Sverige}

"STC har äntligen kommit till Sverige" konstaterade skribenten Eric Dyring i Dagens Nyheter när utställningen "Teknoteket” på Tekniska museet i Stockholm närmade sig invigning våren $1983 .{ }^{464}$ På en yta av 100 kvadratmeter i Parkettsalen bredvid museets huvudentré skulle fysikens och mekanikens lagar uppenbaras genom att besökarna själva aktiverade sig och deltog i experiment vid olika stationer. Nyfikenheten och fantasin skulle härigenom stimuleras och på så sätt lägga grunden för ett fördjupat intresse för naturvetenskap och teknik. "Science-Technological Centers, STC", berättade Dyring, drog stora publikskaror i USA och hade nu kopierats för att bli en attraktion även på svensk mark. ${ }^{465}$

Förutom att ge smakprov från de olika stationerna i utställningshallarna ute på Djurgården kunde artikeln i landets största morgontidning också påpeka för läsaren att idén om att aktivera besökarna var rotad i museets lokaler sedan tidigare. ${ }^{466}$ Dyrings bakåtblickande involverade även hans egen livshistoria. Som tidigare chef för museet hade han förestått 
en verksamhet som ständigt sökte nya former för kommunikation med sina publiker. Skolklasser hade under många år vandrat runt i utställningshallarna och blivit förevisade olika vetenskapliga fenomen. Ett av de mer iögonfallande exemplen i museets historia var demonstrerandet av statisk elektricitet genom en så kallad influensmaskin. Vid kontakt med ett positivt laddat metallföremål reste sig håret på användaren. Exemplet underströk den dubbla funktionen av publikdeltagande. Individens fysiska kontakt med stationen var en förutsättning för experimentet - personen ifråga kunde dock inte (utan spegel) själv bevittna fenomenet, bara känna det. Attraktionen krävde således en större publik som såg och häpnade. ${ }^{467}$

Att den importerade science center-idén nu hade tagit form i en byggnad som tidigare rymt interaktiva attraktioner blev en platsbestämd erinran om konceptets ursprung. "Teknoteket" var dock - som Dyring förklarat för läsarna av Dagens Nyheter - någonting nytt. Det utformades som en försöksverksamhet och höll öppet för publiken i två år med finansiering från Utbildningsdepartementet och Forskningsrådsnämnden. ${ }^{468}$ Den senare hade av regeringen fătt $i$ uppdrag att ägna sig åt spridning av forskningsinformation till barn och unga då detta bedömdes vara eftersatt. ${ }^{469}$ Även här är det möjligt att tala om en pågående omförhandling av kontraktet mellan allmänheten och museivärlden. Forskningsrådsnämnden tillstod att "det passiva betraktandet av föremål i olika montrar" visserligen hade sitt värde, men menade ändå att det kunde beskrivas som "klart otillfredsställande" ${ }^{470}$ Istället talade nämnden positivt om aktiveringen av publiken. "Besökarna vill gärna känna på föremål, på former och kvalitéer. De vill undersöka, pröva, experimentera, leka och fantisera kring företeelser, som kan ge nya erfarenheter och upplevelser." ${ }^{371}$ I ljuset av de nya kraven på publikorienterad verksamhet betraktades science center-rörelsen med sina deltagande aktiviteter som en konkret och löftesbringande åtgärd.

Forskningsrådsnämnden var en mycket viktig aktör i etablerandet av tidiga teknik- och naturvetenskapscentra i Sverige under 1980-talet. Dels finansierade den ett antal pionjärprojekt, dels skapade den förutsättningar för förtätade kontakter mellan svenska institutioner och deras motsvarigheter i Nordamerika. Under åren närmast före och efter 1980 gjorde flera personer studiebesök vid de stilbildande verksamheterna på andra sidan Atlanten, antingen i grupp eller individuellt. Nämnden bjöd också in chefen för Ontario Science Centre, John Tuzo Wilson, som föreläsare under Populärvetenskapens vecka 1983. Vid det arrangemanget närvarade många av de politiker, forskare och skolrepresentanter som 
senare skulle utveckla de första formerna av svenska teknik- och naturvetenskapscentra. ${ }^{472}$

Som tidigare nämnt utgjorde tanken på en större vetenskaplig medborgarbildning hos barn, ungdomar och vuxna en grundläggande tanke i science center-rörelsens idé och utförande. Men med spridningen av konceptet till Sverige följde inte bara en önskan om ökad förtrogenhet hos allmänheten, utan också att den mer specifika frågan om rekrytering av naturvetare och ingenjörer gavs en ny samhällelig plattform. I sin ansökan om medel för "Teknoteket" satte Tekniska museet projektet i relation till behovet av att barn och unga skulle komma "i direkt kontakt med naturvetenskap och teknik, bland annat för att stimulera dem att söka en fortsatt utbildning inom dessa områden”. ${ }^{473}$ Avsikten låg väl $\mathrm{i}$ linje med en av museets sedan tidigare självpåtagna uppgifter: att säkra industrinationen Sveriges återväxt av forskare och tekniker. De uttalade motiven ger oss också möjlighet att förstå villkoren för utställningarnas dubbla funktioner, den didaktiska och den politiska; att intressera, aktivera, motivera, lära ut och rekrytera framstod härigenom som länkar i samma kedja. ${ }^{474}$

Som jag tidigare påpekat är det i studiet av naturvetenskapernas utbildningshistoria under 1900-talet möjligt att visa hur flera praktiker i gränslandet mellan skola och fritid pendlade mellan att drivas av uppenbart meritokratiska ambitioner och mer medborgerligt bildande. ${ }^{475} \mathrm{Om}$ tävlingar som Unga Forskare och Skolornas fysiktävling fungerade särskiljande och utmärktes av elitiserande drag, hade "Teknoteket" snarare rakt motsatt profil med en inkluderande verksamhet som riktade sig till alla barn och ungdomar. Som arenor för out-of-school science education skapade utställningar av sådant slag möjligheter för ett umgänge med vetenskap utanför skolans väggar, antingen i bunden form som undervisning eller som mer renodlad fritidssysselsättning på lov, helger eller efter skoldagens slut.

Även den publika framgången skulle "Teknoteket" ha gemensamt med sina nordamerikanska förlagor. Trots att den bara var en försöksverksamhet i blygsam skala lockade den 150 ooo besökare under säsongen 1983/1984. Museets avsikt var dock att skapa en större anläggning och ett mer genomarbetat projekt. I den kongress- och utställningshall som kallades Teknorama öppnade 1985 en utställning med namnet "Upptäcka, Utforska, Uppleva". Ett "minitek" på 100 kvadratmeter med experiment för barn mellan två och sex år var avskärmat från huvudutställningen, 


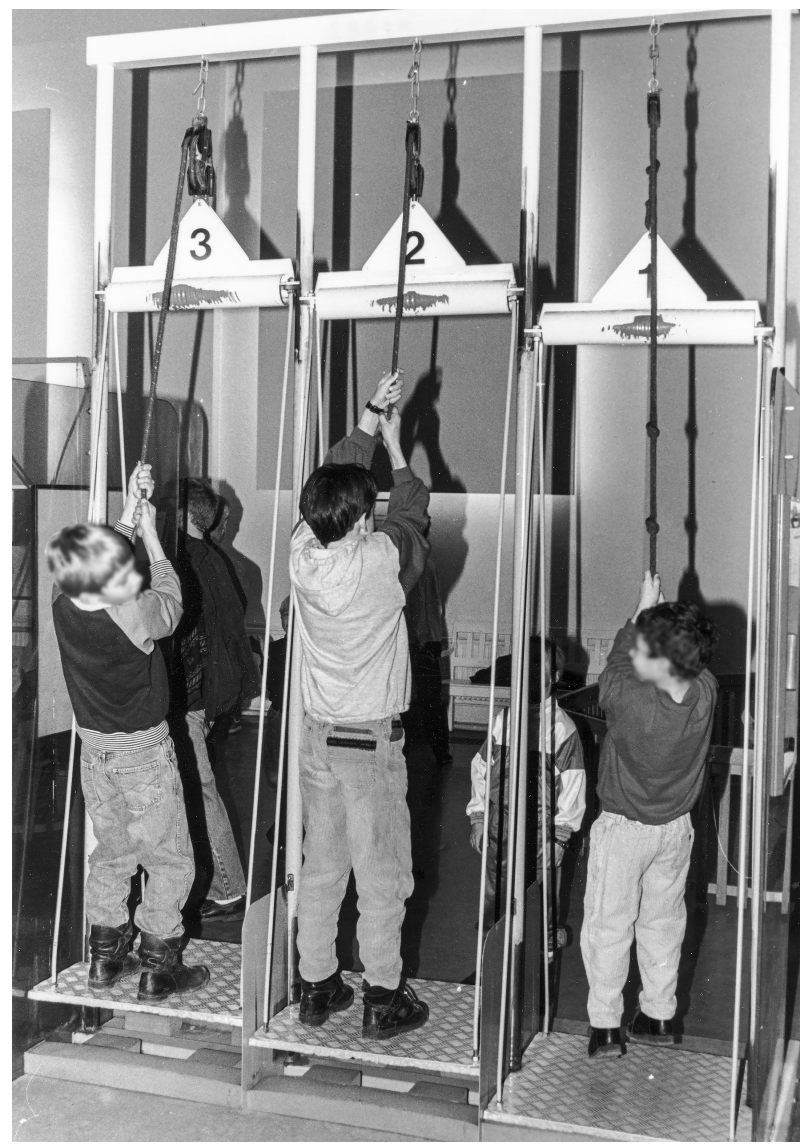

Bild 20. Teknorama I - Upptäcka, Utforska, Uppleva från 1992. Stationen "Lyft Dig Själv" innebar enkla hissanordningar där besökaren kunde lyfta sig själv med hjälp av ett, två eller fyra block. (Foto: Kay Danielsson/Tekniska museet)

som omfattade omkring 600 kvadratmeter interaktiva aktiviteter där publiken möttes av cirka 60 experimentstationer med förklarande skyltar. Vid detta tillfälle hade finansiärerna utökats med privata stiftelser och organisationer. ${ }^{476}$

Som Eric Dyring berättade i Dagens Nyheter var många av stationerna på Tekniska museet kopierade från sina förebilder. Projektledaren Inga-Britta Sandqvist, som själv gjort flera resor över Atlanten, stod inför utbyggnaden till Teknorama i kontakt med rörelsens förgrundsfigurer Oppenheimer, 
Danilov och Tuzo Wilson för ytterligare råd och studiebesök. ${ }^{477}$ Det gjorde att både "Teknoteket" och "Upptäcka, Utforska, Uppleva" på många sätt återgav utställningskulturen i USA och Kanada, inte minst med avseende på hur medieformerna bestämde uttrycken för deltagandets didaktik. "Experimenten" vid de olika stationerna styrde mötet mellan människa och objekt genom att avkräva särskilda rörelsescheman, positioner och avstånd. Publiken kunde även här engageras på flera sätt. De som utförde experimenten skulle lära sig genom att göra, de andra genom att betrakta.

Men utställningen som koncept och materiell upplevelse skapades inte endast i nätverket av museipedagoger och deras utländska inspirationskällor. Ett möte anordnades exempelvis också där näringslivet inbjöds att komma med synpunkter på utformningen. Bakom inbjudan stod - förutom museet - Sveriges Verkstadsförening och Svenska Arbetsgivareföreningen. Här stod bland annat att läsa:

Vi tror att Teknorama kommer att väcka stort intresse hos ungdomar. Vad som där visas experimentellt borde kunna knytas till den tekniska verkligheten i olika företag. Härigenom skulle ungdomar kunna stimuleras till tekniska studier och arbete i industrin i ökad utsträckning, något som borde vara betydelsefullt både för dem själva, företagen och samhällsutvecklingen. ${ }^{478}$

Formuleringarna visade hur närvarande den vetenskapspolitiska dagordningen var, och blottlade den långsiktiga påverkan som man på många sätt hoppades utöva företrädesvis på den yngre publiken.

Om "Teknoteket" och "Upptäcka, Utforska, Uppleva" var initiativ som tagits inom den befintliga museikulturen, visade andra exempel på den institutionella mångfald som tidigt kom att prägla uppförandet av teknik- och naturvetenskapscentra i Sverige. Vid de relativt unga tekniska högskolorna i Luleå och Linköping hade "naturvetarkrisen" uppfattats som ett akut hot i slutet av 1970-talet. För att säkra utbildningarnas överlevnad sökte högskolorna nya aktiviteter för att barn och ungdomar tidigt skulle komma i kontakt med teknik, i förhoppningen om en lokalt förankrad återväxt på lång sikt. ${ }^{479}$ Initiativet i Luleå döptes inledningsvis till "Teknikcentrum" och utarbetade med pengar från Forskningsrådsnämnden bland annat försöksprojekten "Lek med teknik" och "Från malm till maskin" åren 1980-1985. Även här var finansierade utbyten med stilbildande institutioner utomlands vanliga. Studiebesök vid olika 
science centers, myndigheter och universitet gav inspiration till utformningen av det egna formatet. ${ }^{480}$

Båda försöksprojekten i Luleå utformades till stor del som deltagande aktiviteter och bereddes till en början plats i högskolans egna lokaler. De knöts till regionens starka dominans av geologiskt grundad verksamhet; i utställningarna "Gruvan" och "Malmletning" fick barnen prova på magnetseparering av malm, borrning och laboratoriebaserade sprängförsök. De gavs också tillfälle att delta i förädling av malm för att möjliggöra tillverkning av exempelvis kopparmynt. Vilken åldersgrupp man vände sig till varierade. I kurserna "Småforskare" anpassades aktiviteterna till olika elevkategorier - en förskolegrupp, en grupp tredjeklassare och en grupp åttondeklassare. ${ }^{481}$ Rekryteringstanken var explicit närvarande i hur man betraktade verksamheten. I en intervju betonade föreståndaren och en av initiativtagarna AnnMarie Israelsson att målet med "Teknikcentrum" var "att stimulera barnens nyfikenhet, experimentlusta och skapande förmåga. Samt inte minst att öka deras teknikintresse inför framtida yrkesval". ${ }^{482}$

Inom historiska och sociologiska studier av naturvetenskaplig verksamhet har man under de senaste decennierna kommit att intressera sig alltmer för geografiska perspektiv, ibland benämnt som "den rumsliga vändningen". En mängd olika arbeten har understrukit behovet av att studera platsens betydelse för både produktion och spridning av kunskap. Lokaliseringen av möten mellan vetenskap och samhälle styrs, visar sådana studier, sällan av slumpen. Snarare följer inrättandet av rummet ofta en platsens politik där arkitektur, läge och areal bestäms av sammansatta överväganden där kulturellt och socialt påverkade resonemang på nationell och lokal nivå blandas med den tillskrivna betydelsen av vetenskapliga verksamheter. ${ }^{483}$

I likhet med etablerandet av "Teknoteket" och "Upptäcka, Utforska, Uppleva" ute på Djurgården skulle Luleås "Teknikcentrum" i sin specifika kontext understryka rekryteringsfrågans platsspecifika betydelse. Stockholmsprojekten hade förlagts till en redan befintlig institution med historiskt rotade praktiker, något som laddade dem med en särskild sorts anciennitet. I Luleå var det istället framtiden som styrde meningsproduktionen, framförallt med avseende på den geografiska regionen. "Teknikcentrums" geoteknologiska profil hade redan från början formats av områdets gruv- och bergsindustri och av naturresurserna i skogen, vattnet och malmen. Det var också utifrån regionalpolitiska argument man sökte finansiering. I ansökan till Forskningsrådsnämnden framställdes projektet som en mötesplats av mycket stor betydelse: 
Vi betraktar högskolan i Luleå, inte bara som en utbildningsanstalt utan också som en kulturell resurs i vår region. Vi bör därför medverka till att flera barn får tillgång till den kulturella och intellektuella stimulans som kontakten med teknisk och naturvetenskaplig forskning kan ge. Särskilt viktigt är detta med tanke på det minskade intresset för högre tekniska och naturvetenskapliga studier som de senaste åren gett utslag i vikande siffror för antagning till sådan utbildning både vid högskolan i Luleå och vid universitetet i Umeå. En fortsatt utveckling i denna riktning kan vara ödesdiger för hela det norrländska samhället. Det är följaktligen också från denna utgångspunkt viktigt att stimulera barns och ungdomars intresse för teknik och naturvetenskap. ${ }^{484}$

Den ödesmättade tonen hade sin grund i bedömningen av "Teknikcentrum" som en räddningsinsats, inte endast för ingenjörsutbildningarna och högskolan utan i förlängningen för etablerandet av Norrland som en region med teknikvetenskaplig legitimitet. När högskolan invigdes ett decennium tidigare hade dess platsbestämda roll som kunskapsproducerande center varit tydlig. I kampen med andra delar av landet för att bli hemort åt Sveriges tredje tekniska högskola hade norrlandsförslaget först förlorat mot Lund 1963. Genom den så kallade Norrlandsberedningen och därefter framgångsrik lobbyism mot regeringen Palme lyckades dock ett beslut utverkas om att inrätta en maskinteknisk utbildningslinje och att KTH:s sektion för bergsvetenskap flyttades till Luleå. ${ }^{485}$ När portarna till det nygrundade lärosätet slogs upp var det inte bara Luleå som bar upp dess existens. Viss verksamhet var också föreslagen att hamna i Umeå och Skellefteå - sammantaget kallades satsningen uppbyggandet av "högre teknisk utbildning och forskning i övre Norrland" och bedömdes av regeringen vara av stor betydelse för samhällsutvecklingen i hela landsändan. ${ }^{486}$

Platsens politik präglade anknytningen av "Teknikcentrum" till högskolan på mer än ett sätt. Att utställningarna inhystes i lärosätets lokaler gav de båda verksamheterna en ömsesidig förstärkning av motiven för sin existens. Medan högskolans vetenskapliga status skänkte trovärdighet åt "Teknikcentrum", antogs den senare bidra till att uppfylla kraven på studentrekrytering, vetenskaplig återväxt, resultatspridning och forskarsamhällets dialog med allmänheten.

När utställningarna successivt permanentades kom de så småningom att lyftas ur de ursprungliga lokalerna. I en fristående byggnad, men på högskolans område, invigdes Teknikens Hus 1988 med utökad finansiering 
från samtliga Norrbottens kommuner, regionanknutna företag som LKAB, SSAB och Vattenfall, men också från privata stiftelser. De tekniknära verksamheter som presenterades innanför dörrarna anknöt fortfarande i huvudsak till gruvindustrin, stålverket och vattenkraften. Besökarna fick bland annat styra ett vattenkraftverk i miniatyr. ${ }^{487}$

Byggandet av Teknikens Hus är ett exempel på inrättandet av nya samhälleliga ytor för naturvetenskapligt och tekniskt utbildande aktiviteter. Som Oppenheimer visat i The Palace of Fine Arts i San Francisco kunde rum för vetenskapligt lärande också skapas i äldre lokaler som ursprungligen var avsedda för annan verksamhet. Initiativet att grunda "Tom Tits Experiment" i Södertälje konsthall 1985 togs utanför etablerade institutioner som museer och akademier. Det avvek således från mönstret att produktionen och distributionen av vetenskaplig kunskap ägde rum $\mathrm{i}$ nära anslutning till varandra. I andra avseenden liknade dock etablerandet till stora delar tillvägagångssättet för "Teknoteket" och "Teknikcentrum". Initiativtagaren Klas Fresk verkade i början av 1980-talet som nybliven lärarutbildare i naturvetenskapliga ämnen vid Högskolan för lärarutbildning i Stockholm. I den miljön var frågan om ungdomars intresse för naturvetenskap och teknik ett återkommande tema. Fresk var också en av dem som närvarade vid Populärvetenskapens vecka 1983 och såg chefen för Ontario Science Centre framträda. Entusiasmerad av idéerna skaffade han sig ett uppdrag och finansiella resurser av högskolan att utveckla liknande aktiviteter i Sverige. Tillsammans med flera andra av pionjärerna inom den svenska rörelsen för teknik- och naturvetenskapscentra företog han kort därefter en resa över Atlanten för studiebesök. Med stöd i omgångar från olika institutioner och finansiärer tog försöksprojektet $\mathrm{i}$ Södertälje konsthall form 1985 med syftet att öka barns och ungdomars intresse för naturvetenskap och teknik. ${ }^{488}$

Utställningen "Tom Tits Experiment - vetenskapliga förströelser" höll öppet i drygt två månader med interaktiva experiment på temat jämvikt och balans. Varje dag kom 800-1 000 besökare och verksamheten användes flitigt av bland annat skolor, förskolor och lärarutbildningar. ${ }^{489} \mathrm{I}$ likhet med de andra exemplen expanderade Tom Tits Experiment rumsligt efter hand. När verksamheten permanentades flyttade den in i Svenska Centrifug AB:s gamla industribyggnad i Södertälje. De slitna lokalerna ansågs rimma väl med de egna grundidéerna om det ofärdiga experimenterandet och oömma hanteringar av föremål. Av samma anledning - att nyttja husets historia - lät man därför elskåp, kranar och dosor som 
för länge sedan förlorat sin funktion sitta kvar. ${ }^{490}$ Även i samband med finansieringen av den fortsatta utställningen gjorde sig platsens betydelse påmind. Olika bidragsgivare knöt olika förhoppningar till verksamheten; medan Socialdepartementet och Forskningsrådsnämnden hoppades på ökad rekrytering till naturvetenskap och teknik, uttryckte Södertälje kommun sin tilltro till att nya arbetstillfällen skulle skapas på lokal nivå. ${ }^{491}$

När utställningen hade växt så att den upptog huvuddelen av byggnaden fortsatte den rumsliga expansionen bortom fabriksväggarna. Utanför entrén anlades en park - "Tom Tits trädgård" - som mer än fördubblade verksamhetens yta. Förutom de tillkommande kvadratmeterna bedömdes en utomhusanläggning erbjuda större möjligheter att ge besökarna andra upplevelser än de förväntade. ${ }^{492}$

Efter de formativa åren i början av 1980-talet tillkom flera science center-anläggningar runt om i landet. Snart tillhörde Teknorama, Teknikens Hus och Tom Tits Experiment de mer etablerade verksamheterna. Men expansionen under 1980-talet var inte endast geografisk. Institutionerna i Stockholm, Luleå, Södertälje och på andra håll kännetecknades också av ständigt stigande ambitionsnivåer med avseende på kunskapsförmedling. De olika lärandepraktiker som utvecklades på de tre orterna var inte begränsade till stationerna och experimenten själva. I varierande former förekom även regelrätt undervisning. Detta förstärkte redan existerande inslag inom 1900-talets museikultur som gjort skolklassers besök till någonting naturligt. Visserligen var besökaren som kom på sin fritid fortfarande ett slags idealtyp för planeringen. Sådana personer mötte olika former av vägledning - de flesta institutioner förefaller ha pendlat i sin verksamhet mellan självinstruerande stationer, informationsskyltar och värdar som på plats vägledde publiken. ${ }^{493}$

Men minst lika mycket riktades utställningarna till inplanerade mottagningar av skolklasser och deras lärare. Vid Teknorama hade undervisningen formen av introduktioner, rundvandringar på egen hand och sammanfattande genomgångar med frågestunder. Tanken var att inte upprepa skolornas verksamhet utan att istället komplettera den. ${ }^{494}$ Förutom denna undervisning på plats utarbetades efter hand också böcker och lärarhandledningar som ett komplement till de fysiska utställningarna. ${ }^{495}$ Under senare delen av 1980-talet och i början av 1990-talet tilldelades ett flertal andra liknande institutioner ekonomiskt stöd från både Forskningsrådsnämnden och regeringen. Finansieringen knöts allt oftare till försöksverksamheter med utveckling av lärarfortbildning i naturvetenskap 
och teknik. ${ }^{496} \mathrm{I}$ de programtexter som omgav sådana satsningar framträdde dels allmänbildande ambitioner, dels formuleringar vilka mer explicit talade om "teknik/naturvetenskapscentra som instrument i rekryteringen till naturvetenskaplig och teknisk utbildning". ${ }^{497}$

Även inom utbildningshistorisk forskning har "den rumsliga vändningen" under det senaste decenniet genererat ett ökat fokus på kunskapens geografiska och materiella betingelser. Det har bland annat skapat ett allt större intresse för andra ytor och objekt än dem som traditionellt uppmärksammas i samband med lärande. Detta gäller också för forskningen om hur kunskap och pedagogiska koncept förflyttas mellan länder och institutioner. ${ }^{498}$ Utbildande miljöer helt utanför skolans fysiska rum är dock fortfarande ett relativt outforskat område, åtminstone med avseende på naturvetenskap. Fler historiskt inriktade studier behövs för att förstå vilken betydelse sådana platser har haft både som läromiljöer och samhälleliga ytor reserverade för vetenskaplig verksamhet. ${ }^{499}$

De allt högre didaktiska ambitionerna inom den svenska rörelsen för teknik- och naturvetenskapscentra kan i en mening betraktas som en vidareutveckling av nytänkandet inom Skolöverstyrelsens projekt för undervisning och lärarfortbildning under 1970-talet. Tillkomsten av nya rum och texter för lärande materialiserade science center-institutionernas roll som ett slags filialer till den traditionella utbildningen vid skolor och högskolor. När Tom Tits Experiment senare öppnade sin första regelrätta förskoleverksamhet i anslutning till sina egna lokaler innebar det att gränserna mellan skolan och museivärlden luckrades upp ytterligare. Det väcker också frågan om i vilken grad det fortfarande är meningsfullt att skilja mellan "formellt" och "informellt" lärande av naturvetenskap och teknik..$^{500}$

Sammanfattningsvis bidrog de nya institutionernas verksamhet till att förstärka bilden av rekrytering till naturvetenskap och teknik som ett problemområde, samtidigt som de utökade den redan växande floran av åtgärder. Ovan har jag framhållit hur verksamheten präglades av olika deltagandeformer vilkas kunskapsförmedlande funktioner var intimt sammanvävda med politiskt förankrade förhoppningar om att besökarna skulle förmås att intressera sig mer för naturvetenskap och teknik, även som yrke. Detta gällde i förhållande till såväl barns lärande som de vuxnas utbildning i hur elever skulle förmås finna större meningsfullhet i dessa ämnen. De olika sätten att utforma och finansiera verksamheten understryker att intresseorganisationer spelade en stor roll vid sidan av 
myndigheter och näringsliv. Den självständighet som dessa aktörer gav prov på visar också att deras förhållande till mer resursstarka motsvarigheter som stat och näringsliv inte endast var passivt och vidareförmedlande.

\section{Unga Forskare rekryterar yngre}

Själva framträdandet på skolorna - "showen" - har som främsta uppgift att väcka uppmärksamhet. Det går inte att ställa sig rakt uppoch-ned och tala om naturvetenskap och teknik, för att sedan tro att eleverna kommer att bli intresserade. För att väcka deras intresse och måhända deras insomnade hjärnor, måste vi visa uppseendeväckande ting och experiment. Det får inte finnas någon "dötid" under själva framförandet. ${ }^{501}$

Ovanstående citat är hämtat från en presentation av Unga Forskares "skolturné" som pågick under åren 1987-1988 då man genom en uppsökande verksamhet ville förmå fler elever att närma sig naturvetenskap och teknik som utbildning, yrke och livsstil. Genom två kampanjer besöktes sammantaget 80 högstadie- och gymnasieskolor i norra och mellersta Sverige. Huvudnumret var en "vetenskapsshow" med figurritande laserutrustningar, spännande kemiexperiment och astronomiska bildspel för eleverna. ${ }^{502}$

Trots en ideell bas, en ansträngd budget och ett språkbruk som ibland avvek från mer "vuxna" aktiviteter var bakgrunden, strategierna och projektets raison d'être lika medvetet formulerade som hos Teknorama och Tom Tits Experiment. Idén om en ambulerande "vetenskapsshow" utgjorde dock en inverterad form av konceptet för teknik- och naturvetenskapscentra: istället för att avdela eller uppföra specifika rum i samhället för ett entusiasmerande umgänge med vetenskap förde förbundet ut attraktionen till eleverna i deras vanliga läromiljöer.

Utgångspunkten för projektet var att det skulle erbjuda något som skolorna själva inte kunde ge. Projektledaren Göran Cronwall kontrasterade Unga Forskares initiativ mot den formella utbildningens begränsningar: "Genom att väcka elevernas intresse med hjälp av uppseendeväckande fenomen och teknik - sådant som nästan inte existerar ens i skolans sinnevärld - skulle vi kanske få dem att själva engagera sig i föreningar och där t.ex. upptäcka att holografi faktiskt är vansinnigt roligt." ${ }^{303}$ Syftet var dock mer utförligt än så. För tänkbara finansiärer framställde förbundet 
sin ambition som att dels få "högstadieelever, i synnerhet flickor, att välja N-och T-linjen på gymnasiet", dels locka "gymnasister till vidare studier inom N- och T-sektorn". ${ }^{504}$

Vid tidpunkten för turnén hade Förbundet Unga Forskare knappt två decennier bakom sig som intresseorganisation. År 1969 hade det bildats ett riksorgan för att kunna företräda de många lokala ungdomsföreningar som fanns ute i landet. Dessa var nästan alltid knutna till gymnasieskolornas naturvetenskapliga utbildningar. På skolorna fanns resurser i form av ändamålsenliga lokaler, men också lärare som engagerade sig på fritiden och på så sätt möjliggjorde ett lärande utöver vad den lektionsbundna undervisningen förmådde. Lärarnas involvering i föreningarna var också viktig för att bygga upp nätverk med andra skolor. ${ }^{505}$

Förutom den löpande verksamheten i de lokala föreningarna var namnet Unga Forskare sedan 1963 starkt förknippat med tävlings- och uppfinnarkulturen i den årliga utställning som behandlades i föregående kapitel. Den delen av verksamheten sköttes under de första femton åren av en separat stiftelse med Tekniska museet och tidningen Industria som drivande aktörer. ${ }^{506}$

Men även om de båda verksamheterna i formellt avseende var åtskilda, var etablerandet av vetenskapliga föreningar och utställningar på många håll intimt sammanbundna. Som tidigare nämnt hade science fairs för ungdomar växt fram på bred front $\mathrm{i}$ USA under mellankrigstiden. Bakom dessa arrangemang låg ofta föreningar - science clubs - som på många ställen uppstod vid mer välbeställda skolor i storstäderna. Efter hand framträdde också medvetna försök att från amerikanskt håll sprida dessa vetenskapliga fritidsaktiviteter internationellt. Under kalla kriget sågs uppbyggandet av ett internationellt nätverk som en fredsfrämjande insats och ett sätt att visa på vetenskapens inneboende neutralitet. I detta sammanhang spelade den vetenskapspopulariserande organisationen Science Service inledningsvis en betydande roll, inte minst förde dess direktör Watson Davis ut den nationella modellen till överstatliga sammanhang som Unesco, varifrån den senare spreds vidare. ${ }^{507}$

När Utställningen Unga Forskare presenterades i Sverige i början av 1960-talet var det med inspiration av amerikanska förlagor. Personliga kontaker mellan Davis och svenska eldsjälar som Sigvard Strandh vid Tekniska museet gjorde att tävlingen reproducerade mycket av sitt amerikanska ursprung. Samtidigt fanns det faktorer som gjorde att det nya initiativet inte helt och hållet framstod som en direktimport från 
Science Service. I Sverige existerade redan en tradition av vetenskapliga sammanslutningar i form av de gamla läroverksföreningarna ute i landet. En del av dem hade grundats redan i slutet av 1800-talet, medan många andra bildades under den första halvan av 1900-talet. ${ }^{508}$ I huvudsak var det realgymnasiets studenter som bar upp föreningarna och odlade en kultur där naturvetenskap framställdes som en praktik för unga män ur den övre medelklassen. Typiska aktiviteter var föredrag i något vetenskapligt ämne, debatter eller det gemensamma utförandet av experiment. Ibland besöktes föreningarna av kända forskare, ibland gjorde de själva resor till universiteten. Sammantaget skapades en kultur som under första halvan av 1900-talet kunde fostra till självbilden av att tillhöra en framtida vetenskaplig elit. ${ }^{509}$

Aktivitetsgraden i föreningarna hade dock sjunkit under 1960-talet. I och med att tävlingen instiftades 1963 och kontakterna uppstått mellan Strandh och Davis fick klubbarna delvis nya drivkrafter för sin verksamhet. Även om de traditionella inslagen kvarstod på dagordningen inlemmades föreningarna successivt $\mathrm{i}$ en internationellt växande tävlingskultur där tanken på enrollering blev mer uttalad än tidigare. ${ }^{510}$

Om andra rekryteringsinitiativ bidrog till en rumslig expansion av vetenskapligt utbildande aktiviteter, var föreningarna i hög grad något som utökade tidsdimensionen. Till stor del berodde det på att verksamheten förestods av ungdomarna själva. På så sätt fostrade den till ett betydande mått av självstyre och förutsatte att individen på egen hand eller tillsammans med andra unga utvecklade ett beteende där umgänget med naturvetenskapliga eller tekniska praktiker antog drag av en livsstil.

De delvis förändrade motiven för klubbarnas aktivitet sammanföll efter hand med Skolöverstyrelsens arbete under 1970-talet. I sina ambitioner att främja rekryteringen hade $\mathrm{N}$-gruppen tidigt identifierat Förbundet Unga Forskare som en tänkbar samarbetspartner. Föreningsverksamheten uppfattades som central för statens möjligheter att nå målen om en starkare tillströmning till de önskvärda utbildningarna - N-gruppen menade att Unga Forskare hade förutsättningar för att grundlägga ett "livslångt intresse för naturvetenskapliga och tekniska frågor". ${ }^{511}$ Utgångspunkten var densamma som vi sett prov på tidigare, nämligen att skolelever skulle vara lättare att påverka om de fick möta andra ungdomar som redan gjort det önskvärda valet. Under 1972-1975 bistod Skolöverstyrelsen därför förbundet med medel för att utveckla och förbättra sin verksamhet. ${ }^{512}$

Samarbetet förlängdes dock inte och vid tidpunkten för skolturnén 
i slutet av 1980-talet gick kontaktsökandet i motsatt riktning. Nu var det organisationen som uppvaktade myndigheter av olika slag, delvis för finansiering men också för den legitimitet som dessa resurser kunde ge. Forskningsrådsnämnden och länsskolnämnden i Uppsala län anslog medel då man bedömde att projektet väl kompletterade andra sätt att lösa rekryteringsfrågan. ${ }^{513}$

Tillsammans med ytterligare bidrag från ett antal mindre finansiärer genomfördes skolturnéerna 1987-1988 i mellersta och norra Sverige. Arrangemanget genomfördes av medlemmar i förbundet. I framträdanden på 30-40 minuter vid varje skola iscensatte man föreställningar enligt en standardiserad dramaturgi. Först inledde en "ljud- och ljusshow med ett bildspel" följt av figurer ritade av en laserutrustning. Ytterligare attraktioner eller "publikfång" var kemiexperiment med flytande kväve, "jodklockor" och "skumormar". ${ }^{514}$ Under den resterande tiden - när intresset kunde förväntas vara väckt - förevisades bilder på andra tänkbara aktiviteter inom en förening. Avslutningsvis informerades publiken om fortsatta studievägar inom naturvetenskap och teknik. Efter föreställningen fanns det möjlighet att dröja kvar och skriva upp sig på listor för senare kontakt eller få information om hur man startade en förening, samt ta del av skriftlig information om högskolelinjer inom naturvetenskap och teknik. ${ }^{515}$

Unga Forskares Sverigeturné strävade efter att låta eleverna möta experiment som inte var en del av deras vardag. I den meningen var den ett slags upplysningsprojekt där vetenskapliga och tekniska innovationer skulle spridas. Detta drag förstärktes av att turnén rörde sig från centrum till periferi. Den hade utgått från huvudkontoret i Stockholm men reste utanför storstadsregionerna. Vare sig huvudstaden, Göteborg eller Malmö besöktes, men väl Örnsköldsvik, Härnösand och Östersund. I syfte att närvara vid samtliga skolor i inlandet besökte Unga Forskare också orter i glest befolkade områden som Sveg, Ånge och Köping. ${ }^{516}$ En avsikt med denna strategi var att öka förbundets representation i områden där det fanns få föreningar eller där aktiviteten var låg. Norrland var förbundets största distrikt samtidigt som det minsta antalet medlemmar återfanns där. ${ }^{517}$

Turnéerna bedömdes efteråt som lyckade. De ansvariga kunde bära med sig entusiastiska rapporter om omedelbar succé till sina finansiärer och till förbundets huvudkontor i Stockholm. Exempelvis hade mer än tio föreningar startats som en följd av norrlandsresan och många ungdomar uppgavs ha blivit mer intresserade av naturvetenskap och teknik. ${ }^{518}$ 


\section{Publika relationer}

Även om den kringresande vetenskapsshowen var ett försök att ta rekryteringspraktiker till eleverna istället för tvärtom - som i fallet med utställningarna vid Teknikens Hus och Tom Tits Experiment - var det mycket som var principiellt likartat i förfaringssättet. Inte minst gällde detta attraktionen som metod. Föreställningen följde en bestämd ordning där publiken fördes från det uppseendeväckande till det sakliga. De spektakulära inslagen i form av jodklockor och flytande kväve bedömdes vara nödvändiga för att upprätta en relation. Det var samma utgångspunkter som väglett Forskningsrådsnämnden när den argumenterade för behovet av ett nytt publikt kontrakt med allmänheten. Traditionella kommunikationsformer bedömdes inte kunna fånga unga människors intresse i tillräcklig utsträckning. I sin begäran om medel till Forskningsrådsnämnden hade Unga Forskare påtalat att det inte var möjligt "att ställa sig rakt upp-och-ned och tala om naturvetenskap och teknik". Mottagaren av ansökan hade goda förutsättningar att förstå precis vad de menade. ${ }^{519}$

Att döma av både artiklarna i lokaltidningar och kommentarer från besökare var showen hänförande i sin kombination av ljud, ljus, experiment och populariserade fakta. Att pressen skrev om föreställningarna visar också att projektet fick ytterligare publiker för sin förkunnelse. Västerbottens Folkblad publicerade exempelvis en artikel om situationen för lokalföreningarna i Umeå och återgav flera av Unga Forskares viktigaste budskap om den ökade efterfrågan på vetenskapligt intresserade ungdomar. Tidningen nämnde också att verksamheten var i behov av ekonomiskt stöd och att förbundet ogillade stereotyper om den föreningsaktiva eleven:

Förbundet Unga Forskare är en organisation med ett missvisande namn. Egentligen handlar det inte så mycket om forskning i traditionell betydelse - som doktorsavhandlingar på universitetet. Unga Forskare sysslar mera med att fördjupa sig inom naturvetenskapen på fritiden och täppa till de luckor som grund- och gymnasieskolan lämnar i sin undervisning. Men i sin presentation är de noga med att tala om hur roligt de har tillsammans, att även de festar. Precis som "vanliga" ungdomar. ${ }^{520}$

Budskapet från förbundet förmedlades således i flera led och gjorde skolturnén till en medial händelse med tilltagande regional räckvidd. 
Att de publika relationerna är viktiga för att förstå vetenskapens framflyttade positioner under 1800 - och 1900-talen har upprepats i allt fler studier inom sociologisk och historisk forskning. Min analys av Unga Forskares skolturnéer och mötet med de hänförda åskådarna är ett exempel på vad vetenskapssociologen Thomas Gieryn kallar att "söka nedströms" i studiet av naturvetenskaplig verksamhet. Med uttrycket vill han peka på behovet av att se vetenskapen sådan den framträder när den möter allmänheten och presenterar sig för sin publik. Dessa tillfällen är, menar Gieryn, i flera avseenden mer intressanta att studera än att gå "uppströms" till laboratoriet eller till de vetenskapliga tidskrifterna. Det är först på legitimerande samhälleliga arenor - i domstolar, styrelserum, massmedier eller skolor - som vetenskapen ges en möjlighet att vinna politisk och kulturell bekräftelse. Denna bekräftelse kan exempelvis medge exklusiva anspråk på objektivitet, trovärdighet och epistemologiskt tolkningsföreträde. ${ }^{521}$

Men vad ovanstående exempel visar är också att publikerna kunde skänka legitimitet åt vetenskapens krav på att få ta plats i samhället, mätt i kvadratmeter och individer. De entusiastiska artiklarna i Västerbottens Folkblad, Sundsvalls Tidning och övriga lokaltidningar spred därför inte bara Unga Forskares budskap. De sanktionerade också betydelsen av förbundets rekryteringskampanjer.

Idéhistorikern Anders Ekström har påpekat att vetenskapen ofta varit beroende av ett publikt tilltal för sin produktion och distribution. Publiken har i det avseendet varit en resurs för vetenskapen i lika hög utsträckning som det omvända. ${ }^{52}$ I försöken att uppmuntra fler unga människor till naturvetenskapliga och tekniska studier framträdde disciplinernas beroende av publiken på mer än ett sätt. Klassrummets och laboratoriets läropraktiker, utställningshallens deltagande didaktik och aulans inspirerande informationsmöten bidrog alla till att iscensätta olika typer av publikpositioner och förhållanden mellan vetenskapen och dess unga åskådare. Den faktiska publiken var de individer som närvarade på lektionerna, slöt upp vid informationskvällar eller tågade iväg till teknik- och naturvetenskapscentra. I kraft av sin fysiska närvaro och ibland även sitt aktiva deltagande var den betydelsefull då den bevittnade och bekräftade vetenskapens anspråk på utökad samhällsrelevans. Enligt samma logik var valet att gå med i en förening eller att skicka in en ansökan till teknisk utbildning en slutgiltig konfirmering av denna betydelse.

I mer abstrakt form fanns de tänkta publiker som behövde skapas och tilltalas. I egenskap av föremål för liberalt styre gjordes skolungdomar till 


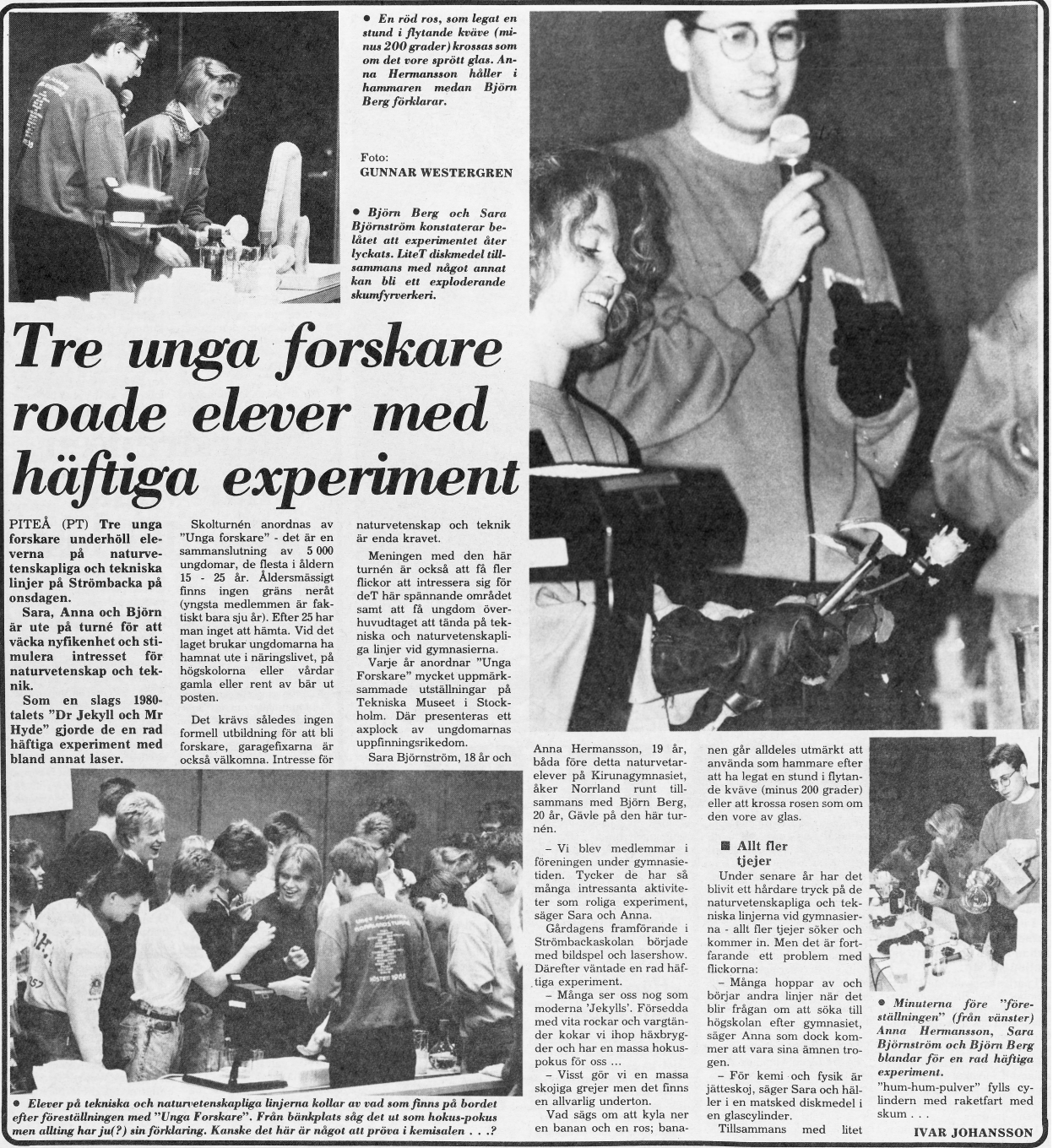

Bild 21. Artikel från Unga Forskares norrlandsturné 1988. (Bildkälla: PiteåTidningen)

projektionsytor för de villkorade framtidsbilder och löften som vetenskapen hade laddats med - ekonomisk tillväxt, produktionsökning och utvecklandet av ett välfärdssamhälle. Dessa framtider gällde dock bara under förutsättning att rekryteringstalen ökade. "Naturvetarkrisen" hade 
visat hur närvarande eleverna blev som en föreställd publik och retorisk resurs i tidningar och på politikens offentliga debattarenor. Åberopandet av behovet av en större grupp naturvetenskapliga och tekniska studenter tillgängliggjorde medel i statsbudgeten, samtidigt som det spelade roll för uppförandet av nya rum i samhället där utbildande aktiviteter inom dessa ämnen kunde påbörjas. ${ }^{523}$

\section{Utökade sammanhang och ambitioner}

Föreställningen om det lustfyllda i att syssla med naturvetenskap och teknik på sin fritid var bärande i det budskap som Unga Forskare sökte förmedla från scenkanten under sina skolturnéer. Detta var även någonting som präglade den internationella marknadsföringen. I sina handböcker om naturvetenskapliga fritidsaktiviteter hade Unesco understrukit vikten av glädje och entusiasm. Ett framgångsrecept för vetenskaplig verksamhet, poängterade man, var tvunget att innefatta rigid disciplin, noggrann omsorg och samvetsgrann kontroll. Allt detta var dock underordnat att aktiviteten måste vara rolig. ${ }^{524}$ Unga Forskare menade att just deras verksamhet var unik i det avseendet. Forskningsrådsnämnden bekräftade tankegången i en utvärdering av skolturnén: "Att naturvetenskap och teknik är roligt kan knappast någon som sett deras lasershow och kemiföreställning tvivla på. Och det som är roligt kan bli ett intresse."’525

Kombinationen hos Unga Forskare av självverksamhet, fritid och krav på glädje tog sig också andra uttryck med avseende på långsiktig rekrytering. Under 1990-talets första hälft anordnade förbundet vetenskapliga läger för barn i grundskolan, så kallade upptäckarveckor. Genom lägerverksamheten nådde förbundets rekryteringsstrategiska åtgärder även de något yngre eleverna. I kollomiljö och med närhet till sol och bad ägnade barnen en vecka under sommarlovet åt att praktisera enklare former av naturvetenskap och teknik under ledning av förbundets medlemmar. Lägren planerades som aktiviteter som skulle bidra till intresset för dessa discipliner. Kemiexperiment, kurser i ytspänningsteknik och raketbyggen blandades följaktligen med mer typiska och traditionella lägerinslag. ${ }^{526}$

Det här kapitlet har handlat om den framväxande science center-rörelsen som tillsammans med Förbundet Unga Forskares olika insatser under 1980-talet möjliggjorde en utbredning av barns och ungdomars rumstidsliga deltagande i naturvetenskap och teknik. Huvudsakligen skedde detta i syfte att etablera en påverkan på unga människor tillräckligt 
stark för att vägleda dem till utbildningar i dessa ämnen. Kapitlet har även handlat om de tilltagande ansträngningarna för att mer specifikt få flickor och kvinnor att välja tekniska yrken, något som ökade unga individers teknikumgänge utanför den reguljära utbildningen. Helgutställningar, sommarkurser och "tjejkvällar" tog andra utrymmen i anspråk än skoltiden. Datakurserna på KTH, veckorna med fordonsteknik på sommarlovet och reparationen av punkterade cykeldäck på Tekniska museet bidrog dessutom till att ytterligare fylla i konturerna av uttrycket out-of-school science and technology education.

Skolan å sin sida hade även den genomgått reformer för att åstadkomma en förändring av beteenden och attityder i förhållande till de aktuella ämnena. Det obligatoriska teknikämnets införande innebar till sin utformning en förhoppning om emancipatoriska effekter och ett makttagande över tekniken i både konkret och abstrakt mening. Flickorna försattes i situationer som avkrävde dem en slutlig bekräftelse på att de kompenserats tillräckligt för tidigare ojämlikheter. Genom sina fria val skulle de bli ingenjörer, tekniker eller naturvetare.

Kapitlet har också handlat om den tilltagande bredden bland aktörerna som pekade ut problemet med att alltför få unga människor valde naturvetenskapliga och tekniska utbildningar. Förutom statliga instanser som Utbildningsdepartementet och Arbetsmarknadsdepartementet, Skolöverstyrelsen och Forskningsrådsnämnden engagerade sig även regionala och lokala myndigheter som länsskolnämnder och kommuner både genom finansiering och att göra mer aktiva insatser.

Den största ökningen av aktörer fanns dock bland enskilda organisationer som Civilingenjörsförbundet, Fredrika-Bremer-Förbundet, tidningen $\mathrm{Ny}$ Teknik, Förbundet Unga Forskare och Tekniska museet. Det sistnämnda är dessutom ett exempel på ett rum varifrån många av de andras aktiviteter utgick. Det var i dessa lokaler som riksfinalen i Utställningen Unga Forskare avgjordes varje år. Till museet valde också Fredrika-Bremer-Förbundets Kvinnor och teknik-grupp att förlägga sin återkommande nationella temavecka. När Teknorama - ett av Sveriges första science centers - öppnades för allmänheten bekräftade det museets roll som en återkommande yta där tillfälliga samarbeten materialiserades. 